\title{
Sample Preparation Techniques for the Analysis of Microplastics in Soil-A Review
}

\author{
Daniela Thomas ${ }^{1, *(\mathbb{C}}$, Berit Schütze ${ }^{1,2}$, Wiebke Mareile Heinze ${ }^{3(1)}$ and Zacharias Steinmetz ${ }^{4, *(1)}$ \\ 1 Thünen Institute, Federal Research Institute for Rural Areas, Forestry and Fisheries, Institute of Agricultural \\ Technology, Bundesallee 47, 38116 Braunschweig, Germany \\ 2 Institute of Environmental and Sustainable Chemistry, Technical University of Braunschweig, \\ 38106 Braunschweig, Germany; b.schuetze@tu-braunschweig.de \\ 3 Department of Soil and Environment, Swedish University of Agricultural Sciences, Box 7014, \\ 75007 Uppsala, Sweden; wiebkemareile.heinze@slu.se \\ 4 iES Landau, Institute for Environmental Sciences, Group of Environmental and Soil Chemistry, \\ University of Koblenz-Landau, Fortstraße 7, 76829 Landau, Germany \\ * Correspondence: daniela.thomas@thuenen.de (D.T.); steinmetz-z@uni-landau.de (Z.S.)
}

Received: 30 September 2020; Accepted: 29 October 2020; Published: 31 October 2020

check for updates

\begin{abstract}
Although most plastic pollution originates on land, current research largely remains focused on aquatic ecosystems. Studies pioneering terrestrial microplastic research have adapted analytical methods from aquatic research without acknowledging the complex nature of soil. Meanwhile, novel methods have been developed and further refined. However, methodical inconsistencies still challenge a comprehensive understanding of microplastic occurrence and fate in and on soil. This review aims to disentangle the variety of state-of-the-art sample preparation techniques for heterogeneous solid matrices to identify and discuss best-practice methods for soil-focused microplastic analyses. We show that soil sampling, homogenization, and aggregate dispersion are often neglected or incompletely documented. Microplastic preconcentration is typically performed by separating inorganic soil constituents with high-density salt solutions. Not yet standardized but currently most used separation setups involve overflowing beakers to retrieve supernatant plastics, although closed-design separation funnels probably reduce the risk of contamination. Fenton reagent may be particularly useful to digest soil organic matter if suspected to interfere with subsequent microplastic quantification. A promising new approach is extraction of target polymers with organic solvents. However, insufficiently characterized soils still impede an informed decision on optimal sample preparation. Further research and method development thus requires thorough validation and quality control with well-characterized matrices to enable robust routine analyses for terrestrial microplastics.
\end{abstract}

Keywords: plastic debris; microplastics; sample pretreatment; soil organic matter; density separation; digestion

\section{Introduction}

A world without plastics seems difficult to imagine given the versatile possibilities for plastics use in all areas of our modern society. Since the advent of plastics mass production in the 1950s, plastics have found their way into everyday consumer products including packaging, mobility, building and construction, and agriculture [1,2]. As a consequence, the global plastic production has increased exponentially from $2 \mathrm{Mt}$ in 1950 to $359 \mathrm{Mt}$ in 2018 [1,3]. The most produced polymers in terms of market shares are high- and low-density polyethylene (PE, 36\%), polypropylene (PP, 21\%), polyvinyl chloride (PVC, 12\%), polyethylene terephthalate (PET, 10\%), 
polyurethanes (PU, 8\%), and polystyrene (PS, 8\%) [1]. Biodegradable plastics like polylactic acid (PLA) or polybutylene adipate terephthalate (PBAT) have a combined market share of $1.3 \%$ [4] but are gaining increasing attention as potential alternatives for conventional polymers.

Current estimates indicate that the extensive use of plastics has already piled up about $5 \mathrm{Gt}$ of plastic waste in the environment, which is equivalent to $60 \%$ of all plastic ever produced [1]. Thompson [5] suggested that $10 \%$ of the produced plastic is entering the world's oceans leaving an unknown sink of $50 \%$; that is $2.5 \mathrm{Gt}$. In line with this, plastic release into terrestrial systems has been hypothesized to be 4-23 times higher than that into aquatic systems [6]. Accumulating microplastics may adversely affect the soil structure and water dynamics $[7,8]$ as well as the fitness of soil biota including earthworms [9], nematodes [10], and plants [11,12]. Nonetheless, only a few attempts have been made so far to better understand the extent of plastic pollution and fate in terrestrial ecosystems for an informed risk assessment. Soil, in particular, has been largely neglected as highlighted by He et al. [13], who only found $4 \%$ of studies published on (micro)plastics actually focusing on soil. Consequently, terrestrial environments most likely play a key role in the world's plastic problem while remaining largely understudied.

Although scarcely quantified but regularly reviewed, plastics are assumed to enter the terrestrial environment via sewage sludge or biosolid application, use of agricultural plastic films, littering, and atmospheric deposition [14-17]. While plastic items may be distributed and transported by air and water erosion [18], bioturbation [19,20], or plowing [21], they fragment into smaller debris due to physical abrasion, exposure to sunlight, or biological degradation [22,23]. Plastic fragments are typically categorized by size into macroplastics $(>5 \mathrm{~mm})$, large microplastics $(1-5 \mathrm{~mm})$, microplastic $(1 \mu \mathrm{m}$ to $1 \mathrm{~mm})$, and nanoplastics $(\leq 1 \mu \mathrm{m})$ [24,25]. In addition, primary and secondary microplastics can be distinguished in terms of particles being produced as such or resulting from fragmentation, respectively. Further classification criteria address the particles' shape, chemical constitution, and material properties [25]. However, the scientific community has not yet established a consensual definition of microplastic properties despite the urgent need for a unified terminology defining criteria on the size, shape, color, and origin of plastics to facilitate the communication and comparability of data [25].

The lack of harmonization is moreover immanent in the plethora of current approaches for the microplastic analysis of soil samples. Whereas Bläsing and Amelung [26] still concluded that plastic pollution in soil remained virtually unknown due to utterly lacking analytics, most recent reviews $[27,28]$ outdo each other with new methods and microplastic findings. However, the majority of reported methods was initially developed for aquatic samples and potentially underestimates the complex nature of soil matrix that keeps sample preparation and microplastics analysis challenging.

Analyzing soil requires careful consideration of the soil profile, soil type, and soil constituents like soil solutes, silicates, (swellable) clay minerals, and soil organic matter (SOM) in varying quantities, grain and aggregate sizes, and densities [29]. SOM is a dynamic, highly heterogeneous mixture of plant- and animal-derived litter at various stages of decomposition. The labile SOM fraction contains easily-degradable molecules like peptides, lipids, and carbohydrates, whereas the more stable humic fraction consists of more complex, polymeric macromolecules [30]. Some of these soil constituents are suspected or have already been reported to interfere with microplastic analysis so that they need to be removed or at least reduced during sample preparation [31-33]. Inorganic fractions such as silicates or clay are often physically removed by density separation, while organic fractions are wetchemically oxidized (see He et al. [13] for a general introduction to analytical methods for microplastics in soil). Apart from their purification efficiency, the selected methods further need to preserve the polymer analytes, which becomes particularly relevant for the analysis of nanoplastics or biodegradable polymers (see Fojt et al.[34] for a recent review on biodegradable plastics in soil). For both, reliable and quantitative analytical tools are still to be developed [35,36].

Previous reviews gave an extensive overview of potential occurrences of microplastics in terrestrial systems $[14,28,37-39]$ and reflected on the suitability of generic methods for soil microplastic 
analysis [26,27]. Our review, in contrast, specifically aims at critically discussing and evaluating current sample preparation techniques for the microplastic analysis of soil. Since soil-specific sample preparation methods are still scarce, we also assessed methods for other solid matrices like sediment or suspended organic matter for their transferability to soil with particular emphasis on their potential applicability and robustness against matrix interferences from various soil constituents.

To this end, we searched Web of Science, CAS SciFinder, Scopus, and Google Scholar literature data bases for search terms including "microplastic" or "plastic debris" in conjunction with "soil", "biosolid", "sediment", or "organic matter". Based on these findings and supplemented with cross-references, we selected 229 original research articles, 37 reviews, 15 books or book chapters, and 25 reports, theses, and guidelines for further evaluation. The reviewed preparation steps included soil drying and sieving, dispersion of soil aggregates, density separation, SOM removal, and extraction with organic solvents. Further, we give a brief overview of suitable options for microplastic analysis after soil sample preparation. We conclude with suggestions for best-practice sample preparation techniques and innovative ideas promoting the development of novel, refined methods for a soil-focused microplastic analysis.

\section{From the Field to the Lab}

\subsection{Sampling Strategies}

The selection of an adequate sampling strategy is the most crucial step in environmental analysis. The choice of the sampling approach is determined by the research question and involves considerations of the hypothesized analyte distribution in the field, potential sources, or site geomorphology. As recently reviewed by Moeller et al. [27], common soil sampling strategies in accordance with ISO18400-102 [40] are equally applicable to microplastics and include hotspot or suspect sampling, systematic grid or transect sampling (as conducted by Piehl et al. [41]), stratified sampling, and random sampling [42]. The sampling area and sampling procedures are to be documented with field notes and photographs. Sampling depths should be defined a priori and reflect the soil profile and management practices like plowing [40,43]. For agricultural fields, for instance, the Federal Soil Protection and Contaminated Sites Ordinance of Germany stipulates a minimum sampling depth of $30 \mathrm{~cm}$ [44]. Yet, the majority of agricultural screening studies for microplastics have so far limited their sampling depth to the topmost $5 \mathrm{~cm}[41,45]$.

Sampling guidelines by the US Department of Agriculture [46] and the US Environmental Protection Agency [47] further recommend taking control samples of the same soil type from an area nearby that is not affected by the contaminant of concern. While this may be challenging for microplastics that ubiquitously enter soil via atmospheric deposition [18], this would offer the advantage of quantifying microplastic background levels, controlling contamination potentially introduced during sampling, or better understanding matrix interferences. The risk of contamination may be reduced by using sampling equipment and containers that are free of plastics $[41,48]$. Plastic sledgehammers or nitrile gloves should thus be avoided [49].

The number of samples per site depends on the spatial extent of the investigated area. In order to cover the spatial variation of an exemplary field with $0.05-1$ ha, German legislation [44] recommends subdividing each field into at least three subplots. For each subplot, one composite sample consisting of 15-50 subsamples ha ${ }^{-1}$ should be drawn [40]. While composite sampling has already been adopted by numerous microplastic field studies to increase sample homogeneity and representativity $[48,50,51]$, others took single samples only [41,42,45].

Minimal, yet representative sample quantities are typically guided by the soil's largest grain size. In accordance with ISO 17892-4 [52] and ISO 18400-102 [40], a sample quantity of at least $500 \mathrm{~g}$ is required for a fine soil with particles sizes smaller than $2 \mathrm{~mm}$. This is in line with existing microplastic screening studies of agricultural and floodplain topsoils that involved sample quantities of $300 \mathrm{~g}$ to several kilograms per plot $[41,45,48]$. By contrast, Lwanga et al. [51] only took $50 \mathrm{~g}$ of garden soil 
for the investigation of plastic transfer along a terrestrial food web. Larger sample quantities are generally advisable in order to acknowledge the heterogeneous distribution of discrete microplastic particles in soil. However, sample quantities of several kilograms usually increase both the sampling and analytical effort. Furthermore, removing large quantities of fertile agricultural soil for sampling purposes may be contrary to sustainability efforts and economic interests of farmers and land owners. Here, stochastic particle distribution models [53] may help to find optimum, representative sample quantities for a given soil texture and the expected microplastic particle sizes and concentrations.

\subsection{Soil Characterization}

Methods for the determination of basic soil characteristics like soil texture, bulk density, aggregate stability, $\mathrm{pH}$, redox potential, $\mathrm{SOM}$ or organic and inorganic carbon contents, and cation exchange capacity are detailed in several guidelines, such as ISO 11277 [54], ISO 11272 [55], and DIN EN 15935 [56]. For microplastic analysis, knowledge of the SOM content, carbonates, and soil texture is particularly relevant as these parameters may influence sample preparation and subsequent microplastic quantification. For example, Corradini et al. [42] related decreasing recovery rates after density separation to elevated SOM contents. In addition, microplastics were recovered at higher rates from sandy soils than from loess or clay [57]. However, both studies did not provide information on how soil parameters were obtained. In contrast to Zhang et al. [57], Scheurer and Bigalke [48] found no correlation between the soil texture and microplastic concentration in floodplain soil, but it remained unresolved to what extent potential microplastic relocation processes in the field may have masked microplastic recovery after sample preparation. This suggests that the description of sampling sites and soil characteristics needs to be more comprehensive in order to facilitate interstudy comparisons and to identify additional, yet uninvestigated, factors like $\mathrm{pH}$ or ionic strength potentially affecting sample preparation.

\section{Sample Preparation}

\section{1. (Freeze) Drying}

Drying soil prior to analysis is imperative to obtain a comparable, water-free reference for microplastic contents or particle numbers. Independent of the analyte, ISO 11464 [58] recommends soil drying at $40{ }^{\circ} \mathrm{C}$ until weight is constant. Yet, drying conditions and procedures for subsequent microplastic analysis are still contrasting. Whereas Berg et al. [21] adhered to ISO 11464 [58] and dried the soil at $40^{\circ} \mathrm{C}$ for $72 \mathrm{~h}$, Liu et al. [45] chose $70^{\circ} \mathrm{C}$ for $24 \mathrm{~h}$. However, temperatures above $40^{\circ} \mathrm{C}$ may affect the polymers' physical and structural properties by glass transition, melting, or degradation. For instance, the glass transition temperatures of polybutylene terephthalate, poly(methyl methacrylate) (PMMA), and polyamide (PA) are 40, 50, and $50-75^{\circ} \mathrm{C}$, respectively [59]. Natural rubber and ethylene-vinyl acetate may start melting at temperatures of $30-65^{\circ} \mathrm{C}$ [59]. Temperatures of about $60^{\circ} \mathrm{C}$ typically initiate degradation of biodegradable polymers like PLA and PBAT [4]. This is why freeze drying has been recommended as a more gentle alternative [60]. On the one hand, freeze drying has been reported to break cell walls and soil aggregates and thereby facilitate further sample preparation [60]. On the other hand, temperatures below the glass transition temperature increase polymer brittleness. Frost wedging may further fragment microplastic particles and release additional cellular organic matter. In addition, freeze drying is more time-consuming than oven or air drying and often constrained by the size of the freeze dryer.

\subsection{Homogenization, Sieving, and Sorting}

Prior to further sample processing, soil is recommended to be adequately homogenized manually or by using automatic sample dividers. Laboratory subsamples and retention samples should be at least $200 \mathrm{~g}$ [58]. After homogenization, ISO 11464 [58] further specifies sieving to fine soil $\leq 2 \mathrm{~mm}[57,61$ ]. All subsequent soil analyses are performed on fine soil, and analyte contents are based on fine 
soil as common reference for interstudy comparisons. This contrasts the common definition of microplastics of $\leq 1$ and $\leq 5 \mathrm{~mm}$ [24,25]. Accordingly, Piehl et al. [41] sieved soils to 1 and $5 \mathrm{~mm}$. Liu et al. [45], Huang et al. [62], and Zhou et al. [63] included all fractions below $5 \mathrm{~mm}$. In such cases, large microplastics may cover smaller particles and lead to systematic underestimation during spectroscopic analysis. We thus suggest sieving to 1,2 , and $5 \mathrm{~mm}$ in compliance with standard mesh sizes of commercially available test sieves. Use of a sieving cascade may reduce the work load. However, it is currently poorly understood how excessive sieving might enhance the fragmentation of particles, in particularly aged, biodegradable, or freeze-dried plastics.

\subsection{Dispersion of Soil Aggregates}

As microplastics may be incorporated into soil aggregates and thus not be easily separable from other soil constituents [57], additional preparative steps are required to promote the disintegration of soil aggregates and dispersion of grains. Although specified by ISO 11464 [58], grinding of soil samples for subsequent microplastic analysis will increase particle fragmentation and may induce melting by frictional heat. A simple alternative is initial shaking of soil samples in a dispersion agent such as aqueous sodium hexametaphosphate solution [63-65]. Additionally, ultrasonication has been applied to soils suspended in deionized water $[57,66]$ or in a salt solution prior to density separation [45]. However, adequate sonication levels strongly depend on the soil type, in particular on the aggregate stability [67], and progressive sonication may increase the amount of light-density SOM potentially interfering with density separation. Moreover, it has not yet been systematically assessed if or to what extent chemical dispersion agents or ultrasonication may cause interferences or enhance microplastic fragmentation, respectively. Further method development is thus needed to scrutinize potential adverse effects on microplastic analysis to transfer established methods from soil science to terrestrial microplastics research.

\subsection{Density Separation}

\subsubsection{Separation Principle}

The most common technique to preconcentrate or isolate microplastics from soil is density separation. Density separation exploits the buoyancy of plastic particles in solutions with a higher density than that of plastics $\left(\rho=0.9-1.6 \mathrm{~g} \mathrm{~cm}^{-3}\right)$, while the soil mineral fraction (for instance silica, $\rho>2.0 \mathrm{~g} \mathrm{~cm}^{-3}$ ) remains at the bottom $[68,69]$. To date there is no standardized density separation procedure for microplastic extraction from soils. In principle, the soil sample is mixed with a density solution, and floating plastic particles are collected after a certain amount of time. However, studies vary greatly in terms of sample amounts, applied density solutions, and the technical setup.

\subsubsection{Density Solutions}

Various density solutions have already been used for isolating microplastic from soil, including deionized water, $\mathrm{NaCl}, \mathrm{NaBr}, \mathrm{NaI}, \mathrm{CaCl}_{2}, \mathrm{ZnCl}_{2}$, and sodium heteropolytungstate solutions. Additionally, ethanol, potassium formate, $\mathrm{ZnBr}_{2}$, sodium tungstate dehydrate, and sodium polytungstate (SPT) solutions have been tested for sediments but not yet for soil (Table 1). Apart from density solutions, the applied ratios of soil-to-density solution vary greatly between 1:2 [70] and 1:25 [61]. While soil-to-solutions ratios are often determined by the sample size and technical setup, they may be decisive for microplastic recovery. However, this has not yet been addressed. 
Table 1. Density solutions for the separation of microplastics from solid matrices.

\begin{tabular}{|c|c|c|c|c|c|}
\hline Density Solution & Density $\left[\mathrm{g} \mathrm{cm}^{-3}\right]$ & Evaluated Polymer Type(s) & Sample Type & Remarks & Ref. \\
\hline Ethanol $(96 \%)$ & 0.8 & Light-density SOM & Plant material & Flotation of light-density SOM; no microplastic separation & [71] \\
\hline & 1.0 & PE, PP & & Not suitable for high-density polymers & {$[57]$} \\
\hline $\mathrm{NaCl}$ & 1.2 & $\mathrm{PE}, \mathrm{PP}, \mathrm{PS}, \mathrm{PA}, \mathrm{PC}, \mathrm{PMMA}, \mathrm{ABS}$ & Farmland soil, marine sediment & Not suitable for high-density polymers & {$[45,72]$} \\
\hline $\mathrm{NaBr}$ & $1.4-1.6$ & PE, PP, PS, PET, PVC, PA, PMMA & Agricultural and floodplain soil, sediment & & {$[73,74]$} \\
\hline $\mathrm{CaCl}_{2}$ & $1.3-1.5$ & PE, PP, PS, PET, PVC, PC, PA, PU, ABS & Organic-rich topsoil & $\mathrm{Ca}^{2+}$ may cause flocculation of SOM & [48] \\
\hline Potassium formate & & $\mathrm{PE}, \mathrm{PP}, \mathrm{PS}, \mathrm{PET}$ & Lakeshore sediments & No validation & [75] \\
\hline $\mathrm{ZnCl}_{2}$ & $1.5-1.7$ & PS & Biosolids, soil & Expensive ${ }^{\dagger}$, corrosive, and harmful to the environment, may alter microplastics and cause foaming & [35] \\
\hline $\mathrm{ZnBr}_{2}$ & 1.7 & PE, PP, PS, PET, PVC, PA & Sediment & Expensive $e^{\dagger}$, corrosive, and harmful to the environment & [74] \\
\hline $\begin{array}{l}\mathrm{NaI} \\
\text { SPT }\end{array}$ & $1.6-1.8$ & PE, PP, PS, PET, PVC, PA, PU & Agricultural soil, sediment & Expensivet, harmful to the environment & {$[62,72,74,76]$} \\
\hline $\begin{array}{c}\text { SPT } \\
\text { Sodium tunostate dihydrate }\end{array}$ & $1.4-1.8$ & $\begin{array}{l}\text { PE, PET, PVC, PA } \\
\text { PE PP PS PEE PYC PC PA PU PMM FVA }\end{array}$ & $\begin{array}{l}\text { (Beach) sediment } \\
\text { Sediment }\end{array}$ & $\begin{array}{l}\text { Expensive } e^{\dagger} \\
\text { Fxpensive }\end{array}$ & {$[68,77]$} \\
\hline Sodium tungstate dihydrate & & PE, PP, PS, PET, PVC, PC, PA, PU, PMMA, EVA & Sediment & Expensive $^{+}$ & \\
\hline
\end{tabular}

${ }^{\dagger}>100$ Euros kg $^{-1}$ [79]. 
Deionized water $\left(\rho=1.0 \mathrm{~g} \mathrm{~cm}^{-3}\right)$ and saturated $\mathrm{NaCl}$ solution $\left(\rho=1.2 \mathrm{~g} \mathrm{~cm}^{-3}\right)$ are suitable for separating low-density polymers like PE, PP, and PS from soil mineral matrices, while being cheap, easily available, and not harmful to the environment $[45,57,61,80,81]$. Scheurer and Bigalke [48] reasoned that $\mathrm{Na}^{+}$may further promote dispersion of soil aggregates, which could increase the extraction efficiency. While low-density microplastics can be specifically targeted using deionized water or $\mathrm{NaCl}$ solution, the extraction of denser particles is not possible. This particularly applies to PET $\left(\rho=1.3-1.6 \mathrm{~g} \mathrm{~cm}^{-3}\right)$ and PVC $\left(\rho=1.1-1.6 \mathrm{~g} \mathrm{~cm}^{-3}\right)[48,82]$.

To this end, saturated $\mathrm{CaCl}_{2}$ solution $\left(\rho=1.3-1.5 \mathrm{~g} \mathrm{~cm}^{-3}\right)$ has been proposed due to its low cost $\left(<100\right.$ Euros $\left.\mathrm{kg}^{-1}\right)$ and environmental friendliness [48,83]. However, some unidentified, most likely organic floccules were observed after separation from soil [48]. The authors suggested that divalent $\mathrm{Ca}^{2+}$ caused flocculation of organic substances through ion bridging. Thus, $\mathrm{CaCl}_{2}$ solutions cannot be recommended for the separation of microplastic in SOM-rich samples.

While $\mathrm{NaBr}$ solutions $\left(\rho=1.4-1.6 \mathrm{~g} \mathrm{~cm}^{-3}\right)$ did not result in significant improvement of microplastic recoveries from sediment [74], Liu et al. [73] found that $\mathrm{NaBr}$ outperformed both $\mathrm{NaCl}$ and $\mathrm{CaCl}_{2}$ at separating various plastic types, sizes, and shapes from a range of different soil samples. One reason for this discrepancy was probably the difference in the adjusted densities between both studies: Quinn et al. [74] used $1.4 \mathrm{~g} \mathrm{~cm}^{-3}$, whereas Liu et al. [73] prepared a $1.6 \mathrm{~g} \mathrm{~cm}^{-3}$ solution. This raises the often neglected question of how density solutions are prepared and how this affects extraction efficiencies, once more underlining the need for a uniform protocol for the preparation of density solutions.

Potassium formate solutions $\left(\rho=1.5-1.6 \mathrm{~g} \mathrm{~cm}^{-3}\right)$ were used for separating microplastics from sediments [75,84] but have not been tested for soils so far. With regards to its density, it is reasonable to expect incomplete recovery of higher-density polymers. Yet, its environmental friendliness [85] would make it a solution worth testing.

A comprehensive comparison of different density solutions in sediment revealed that recovery rates of various microplastic types generally increased with the density of the solutions [74]. This trend was independent of the particle size and may therefore equally apply to soil. For denser polymers like PET or PVC, current studies therefore recommend high-density salt solutions such as $\mathrm{ZnCl}_{2}\left(\rho=1.5-1.7 \mathrm{~g} \mathrm{~cm}^{-3}\right)$ or NaI $\left(\rho=1.6-1.8 \mathrm{~g} \mathrm{~cm}^{-3}\right)[6,57,86]$. With prices $>100$ Euros kg ${ }^{-1}$ [79], these salt solutions are 4-10 times more expensive than $\mathrm{NaCl}$ and both classified as environmentally harmful $[87,88]$. Moreover, $\mathrm{ZnCl}_{2}$ is corrosive and may thus degrade microplastics [13]. In addition, Zobkov and Esiukova [89] observed strong foaming when applying $\mathrm{ZnCl}_{2}$ solution to organic-rich sediments. Although the cause was not further investigated, excessive foaming may be problematic for restricted container volumes and pose difficulties for retrieving the supernatant. By contrast, $\mathrm{NaI}$ solution may cause blackening of some filter papers, which may require an additional transfer step to a clean filter [74].

A promising solution is sodium heteropolytungstate $\left(\rho=1.5 \mathrm{~g} \mathrm{~cm}^{-3}\right)$, which was successfully used for separating microfibers from soil and earthworm depurates [90]. Similar solutions, including sodium tungstate dihydrate $\left(\rho=1.4 \mathrm{~g} \mathrm{~cm}^{-3}\right)$ [78], and SPT $\left(\rho=1.4-1.8 \mathrm{~g} \mathrm{~cm}^{-3}\right)[60,91-93]$ were used for sediment samples but have not yet been applied to soil. Enders et al. [60] provided a detailed guidance protocol for an entire microplastic ( $10 \mu \mathrm{m}$ to $5 \mathrm{~mm}$ ) extraction pipeline with SPT solution as separation agent. Nevertheless, SPT is costly ( $>100$ Euros $\left.\mathrm{kg}^{-1}[79]\right)$, and a systematic validation including recovery tests for soil samples is still missing. This impedes comparing the general performance of SPT with more commonly used salt solutions.

In order to maximize separation efficiency and reduce the consumption of higher-density solutions, multiple-step separation procedures have been introduced either by using the same solution several times [45,62] or by applying lower- and high-density solutions sequentially [21,42,72,94-96]. Typically, deionized water $[21,94]$ or $\mathrm{NaCl}$ solution $[72,77,95,96]$ are used first. In a second step, residues may be subjected to $\mathrm{NaI}$ solution to extract high-density polymers. Frere et al. [77] chose sodium tungstate for sediment samples instead and completely recovered PET, PVC, and PA particles 
( $5 \mathrm{~mm}$ ). Corradini et al. [42] even performed a three-step density separation for sewage sludge and soil samples with deionized water, $\mathrm{NaCl}$, and $\mathrm{ZnCl}_{2}$ solution, which increased recovery for all plastics examined, but most significantly for PVC. However, recovery rates were not provided in detail.

Although not examined so far, low-density solutions may be equally valuable for reducing SOM $\left(\rho<1.6 \mathrm{~g} \mathrm{~cm}^{-3}\right)$ [67] in the soil matrix without altering polymers. For example, ethanol $\left(96 \%, \rho=0.8 \mathrm{~g} \mathrm{~cm}^{-3}\right)$ has been suggested for separating plastics from less dense biological material [71]. While such an intermediate treatment step may facilitate and reduce material consumption for further sample preparation, the risk of losing light-density plastics needs to be carefully evaluated. When deciding on several density separation steps, potential trade-offs between improved separation efficiency and increased risks of contamination or loss of microplastics need to be taken into account.

In general, density solutions have proven their suitability for separating microplastics from the soil matrix. Solutions with higher densities like $\mathrm{NaBr}, \mathrm{NaI}, \mathrm{ZnCl}_{2}$, or SPT $\left(\rho=1.6-1.8 \mathrm{~g} \mathrm{~cm}^{-3}\right)$ extract a wide range of polymers at the expense of potentially co-extracting SOM $\left(\rho<1.6 \mathrm{~g} \mathrm{~cm}^{-3}\right)$ [67] and thus require additional purification. By contrast, lower-density solutions (deionized water, $\mathrm{NaCl} ; \rho=1.0-1.2 \mathrm{~g} \mathrm{~cm}^{-3}$ ) may be preferred when targeting specific polymers or for reducing costs, operational effort, or environmental impact. Therefore, the suitability of a specific solution needs to be assessed on a case-by-case basis in accordance with the research question, the soil composition, and polymers of interest.

\subsubsection{Recycling of Salt Solutions}

According to the principles of green chemistry, the quantity, hazardousness, and disposal of chemicals should be reduced as much as possible [97]. Thus, recycling is imperative for expensive solutions and solutions of environmental concern used for density separation. Several recycling attempts have already been described for $\mathrm{NaBr}, \mathrm{NaI}, \mathrm{ZnCl}_{2}$, potassium formate, and SPT. Kedzierski et al. [98] showed that NaI solutions used for density separation of sediments can be recycled up to ten times by evaporation without decreasing the separation efficiency. Another approach evaluated $\mathrm{ZnCl}_{2}$ recycling via membrane filtering $(0.45 \mu \mathrm{m})$ [99]. Over five filtration cycles, microplastic recovery remained above $95 \%$. Potential changes in density or $\mathrm{pH}$ were not reported. Stock et al. [84] recycled potassium formate by filtering, however, without assessing recoveries. Liu et al. [73] constructed an automatic flow system that allowed for immediate recycling and continuous use of density solution. This substantially reduced the needed amount of $\mathrm{NaBr}$ solution and recovery rates remained $>90 \%$. Recycled solutions may be stored either as solution $[73,99]$ or as extracted salt [98]. Although most authors reported cost and material reductions, it remains important to note that recycling and storage require additional working time, materials, space, and energy.

\subsubsection{Instrumental Setups}

The simplest technique for density separation is direct mixing of sample and solution by manual shaking or stirring and subsequent settling in an appropriate sample container $[57,73,86,95]$. However, automated and controlled shaking in overhead [74] or platform systems [21], magnetic [62] or electric stirring [100] may be preferred to increase reproducibility and method standardization.

Containers used for density separation vary greatly, ranging from beakers and separation funnels to more complex setups. Glass beakers are used most widely $[45,62,63,74,89,101]$, followed by bottles [94], Erlenmeyer flasks [35], and centrifuge tubes [42]. In some studies, separation devices were self-built [81,100]. Depending on the container of choice, a $5 \mathrm{~g}$ [42] to up to $6 \mathrm{~kg}$ [100] sample can be processed, requiring $20 \mathrm{~mL}$ to $12 \mathrm{~L}$ density separation solution, respectively. Although rarely specified, the height of the container may be important as it determines the distance between the denser and lighter fraction and thereby the separation efficiency [102]. Furthermore, container materials should be free of plastics to avoid contamination or sticking of plastic particles to the inner surface of the container. 
To further promote separation, Enders et al. [60] designed a spiral conveyor rotating inside a separation funnel to constantly transport the sample upwards. Thereby, the sample disperses more efficiently, which facilitates microplastic separation from the heavier soil matrix. Nuelle et al. [72] proposed an air-induced overflow system, exposing the sample to turbulences by continuous air-bubbling potentially benefiting the separation of lighter particles from denser matrix. The method was efficient at reducing the amount of sediment for further treatment steps. A more advanced setup was developed by Renner et al. [81] using larger air bubbles for dispersion and finer ones as adhesive surfaces for separating microplastics from the matrix. The setup also minimized dead spaces to ensure that no plastic particles would be retained in the container. The method seems promising as $>90 \%$ of microplastic spikes were recovered from sand samples within $20 \mathrm{~min}$. Although the authors propose its suitability for soil samples, an evaluation is still pending. Notably, when Scheurer and Bigalke [48] combined stirring with continuous air-bubbling for soil samples, the method did not result in a significantly higher extraction efficiency. One possible challenge for the applicability of air bubbling systems to soil is that very fine textured, clayey soils or soils with very dense minerals may form a sludge at the bottom of the vessel, blocking the air inlet. Instead, Scheurer and Bigalke [48] used centrifugation to reduce the processing time. While others also centrifuged soil samples in density solutions [21,42], only Scheurer and Bigalke [48] reported recoveries ( $\geq 93 \%)$.

In general, separation protocols vary not only in terms of the density separation procedure but also in treatment times (10 s to $2 \mathrm{~h}[21,72]$ ) and settling times (5 $\mathrm{min}$ to $24 \mathrm{~h}[48,103])$. For adjusting these procedural parameters, plastic and soil mineral particle sizes as well as the SOM content and soil aggregate stability may provide a reference to evaluate suitable settling times [35].

\subsubsection{Sample Collection}

After the separation procedure, microplastics floating on the solution surface need to be collected and isolated for further treatment and analysis. A simple and low-cost approach is to collect microplastics by decanting $[48,57,62,104]$. Since microplastics have the tendency to adhere to the inside of container walls [105], repeated density separations may be necessary to ensure the complete transfer of all microplastics. However, this results in prolonged processing times and increases the risk of contamination. Floating SOM is particularly challenging for the decanting method.

Microplastics can also be further retrieved by suction. First applications involved pipettes to collect synthetic fibres from sludge and soil [61,90]. Scheurer and Bigalke [48] used a vacuum pump to aspirate the topmost layer of the density solution with the microplastics and transferred them to a second vessel for collection. The inherent risk is that particles floating directly on the surface are not collected and are lost for analysis as tubes need to be submerged for vacuum pumping. Rinsing of tubes may also increase the demand of solution media. Adding surfactants such as polysorbate 80 [60] may reduce adhesion to separation equipment. However, this has not been tested for soil so far.

Most of the recently developed systems are based on overflow of the supernatant through the continuous addition of density solution $[35,45,63,72,73,103,106]$. With this, microplastics may adhere not only to inner but also to the outer container walls, which complicates particle collection. Moreover, such open constructions are extremely prone to contamination.

By contrast, separation funnels (see Enders et al. [60] for illustrations) have an outlet at the bottom of the apparatus that is used to drain the settled mineral fraction before collecting the supernatant $[35,72,86]$. Separation funnels are prone to clogging if the outlet is too narrow. This particularly applies to very fine or very coarse soil. Clogging may be mitigated by either adjusting the diameter of the outlet valves [60] or carefully stirring up the sediment. However, the latter would favor particle adhesion to stirrers and might cause the resuspension of fine soil. Nevertheless, separation funnels offer the advantage of using a single container, which reduces dead spaces as well as the risk of contamination and analyte loss.

To further facilitate sample collection, density separation apparatuses were customized in such a way that a bottom chamber containing the dense material can be physically separated from a 
top chamber with the extracted microplastics, for instance, by use of a ball valve $[89,100,102,107]$. Depending on the chamber geometry and the type of ball valve, dead spaces may retain microplastics leading to reduced recoveries. Furthermore, fine clay particles may block the valve after long-term use.

Finally, microplastics are typically collected on membrane filters for subsequent analysis. Depending on the target particle size and analytical approach, decisions need to be made regarding the filter mesh width and material $[108,109]$. A first systematic evaluation of different filter materials was conducted by Löder et al. [109] who found aluminum-oxide and polycarbonate (PC) filters the least interfering with identification via Fourier transformed infrared (FTIR) spectroscopy. However, using filters made from plastic, such as PC [109] or nylon [45], may exclude these polymers from further analysis. While glass fiber filters come in as being useful for particle collection [62,70], they were reported unsuitable for spectroscopic methods [109]. Cellulose-based filters may be chosen instead [21,42,63], but interactions with density solutions may alter filter properties [74]. Thus, potential interferences of altered filter material during analysis need to be tested. Although not always specifically stated, filter mesh size determines the lower size limit for plastic detection. Reported mesh widths are often larger than $5 \mu \mathrm{m}[62,63]$. Consequently, the usage of filters for sample collection implies a systematic loss of the smallest microplastic fraction $(\leq 5 \mu \mathrm{m})$, and the complete nanoplastic fraction $(<1 \mu \mathrm{m})$. This is particularly relevant for thermoanalytical methods, which are theoretically capable of capturing these fractions. Moreover, there is a potential trade-off between minimizing mesh sizes and the filtration capacity, especially for soils high in light-density SOM where filters may easily get clogged.

\subsection{Removal of Soil Organic Matter}

With $\rho<1.6 \mathrm{~g} \mathrm{~cm}^{-3}$ [67] the density of SOM is similar to that of microplastics $\left(\rho=0.9-1.6 \mathrm{~g} \mathrm{~cm}^{-3}\right)[68]$ and can thus be only partially removed by density separation. SOM removal is important as SOM constituents may interfere with subsequent microplastic analysis. Four groups of digestion agents for organic matter removal can be distinguished: (1) alkaline $\mathrm{KOH}$ or $\mathrm{NaOH}$ solutions, (2) acids including $\mathrm{HNO}_{3}$ and $\mathrm{H}_{2} \mathrm{SO}_{4}$, (3) oxidants like $\mathrm{H}_{2} \mathrm{O}_{2}$ or Fenton reagent, and (4) enzymes, for example proteinase K (Table 2) [110]. Different digestion agents may be applied sequentially to optimize removal efficiencies.

Alkaline solutions are typically used for denaturation of proteins in biota. When applied to a floodplain loamy sand containing 5.8\% SOM, however, $\mathrm{NaOH}(1$ and $10 \mathrm{M})$ and $\mathrm{KOH}(1.8 \mathrm{M})$ solutions only removed 35-68\% SOM [94]. The researchers suggested that humins and alkali-insoluble compounds could not be degraded and removed from the sample. In addition, $\mathrm{NaOH}$ resulted in a severe PET and PC mass loss of up to $30 \%$, while $\mathrm{KOH}$ partially degraded PC. Alkaline treatments may even more severely affect biodegradable plastics. Kühn et al. [111], for instance, reported complete loss of a PLA bag after purification with $1 \mathrm{M} \mathrm{KOH}$. 
Table 2. Suitability of digestion agents for the removal of SOM for microplastic analysis.

\begin{tabular}{|c|c|c|c|c|c|c|c|}
\hline Reagent & Sample Type & Evaluated Polymers & Extraction Time $[\mathrm{d}]$ & Temp. $\left[{ }^{\circ} \mathrm{C}\right]$ & SOM Removal Efficiency [\%] & Deteriorated Polymers & Ref. \\
\hline $\mathrm{KOH}$ & Loamy sand & PE, PP, PS, PET, PA, PC, PMMA & 1 & 60 & $30 \pm 20$ & PC & [94] \\
\hline $\mathrm{NaOH}$ & Loamy sand & PE, PP, PS, PET, PA, PC, PMMA & 1 & 60 & $70 \pm 20(1 \mathrm{M}), 60 \pm 40(10 \mathrm{M})$ & PET, PC & [94] \\
\hline $\mathrm{HNO}_{3}$ & Floodplain soil & PE, PP, PS, PET, PVC, PA, PC, PU, ABS & 2 & 90 & Higher than $\mathrm{NaOH}, \mathrm{H}_{2} \mathrm{SO}_{4}, \mathrm{H}_{2} \mathrm{O}_{2}$ & ABS, PA, PET & [48] \\
\hline $\mathrm{H}_{2} \mathrm{SO}_{4}$ & Floodplain soil & PE, PP, PS, PET, PVC, PA, PC, PU, ABS & $1,4,7$ & 90 & Lower than with $\mathrm{HNO}_{3}$ & Not tested & [48] \\
\hline $\mathrm{H}_{2} \mathrm{O}_{2}$ & Loamy sand & PE, PP, PS, PET, PA, PC, PMMA & 1 & 60 & $100 \pm 10$ & PS & [94] \\
\hline $\mathrm{H}_{2} \mathrm{O}_{2}$ & Agricultural soil & PE, PP, PS, PET, PVC, PA, PC, PMMA, ABS & 1 & 60 & Not reported & Not reported & [73] \\
\hline $\mathrm{H}_{2} \mathrm{O}_{2}$ & Sediment & PE, PP, PS, PET, PVC, PA, PC, PU, ABS & 7 & RT & Not reported & PET, PVC,PC, PA, PUR, PP, LDPE & [72] \\
\hline $\mathrm{H}_{2}^{2} \mathrm{O}_{2}$ & Loamy sand & PS, PP, PE, PET, PA, PC, PMMA & 1 & 70 & $110 \pm 10$ & PA, PS & [94] \\
\hline Fenton reagent & Loamy sand & PE, PP, PS, PET, PA, PC, PMMA & 1 & 40 & $110 \pm 10$ & None & [94] \\
\hline
\end{tabular}


Similarly, $\mathrm{HCl}$ and $\mathrm{HNO}_{3}$ have been discussed as potential digestion agents for SOM [26]. Concentrated $\mathrm{HNO}_{3}(65 \%)$ completely removed $\mathrm{SOM}(>30 \%)$ from a floodplain soil whereas $96 \% \mathrm{H}_{2} \mathrm{SO}_{4}$ and $13 \%$ potassium hypochlorite left 3 and $6 \%$ of organic residues, respectively [48]. However, acrylonitrile butadiene styrene (ABS), PA, and PET were partly degraded or fragmented into smaller particles [48].

The majority of studies addressing the removal of SOM used $\mathrm{H}_{2} \mathrm{O}_{2}$ for sample preparation (Table 2). This may be attributed to the fact that $\mathrm{H}_{2} \mathrm{O}_{2}$ has been successfully applied to sediments in previous studies [72,100]. In line with this, Hurley et al. [94] removed 96-108\% SOM from a loamy sand with $30 \% \mathrm{H}_{2} \mathrm{O}_{2}$ at $70{ }^{\circ} \mathrm{C}$. However, PA particles were destroyed and PS particles partly degraded. Experiments at room temperature revealed changes in color and size for PE, PP, PET, PVC, PC, PA, and PU after $7 \mathrm{~d}$ [72]. While effective for removing vegetal litter, degrading effects on microplastics were also mentioned for a three-stage method developed by Duan et al. [112]. Therein, $\mathrm{H}_{2} \mathrm{O}_{2}(30 \%)$ was consecutively added at temperatures of 70 and $100^{\circ} \mathrm{C}$ and left for digestion for $1-7 \mathrm{~h}$. With regards to previous findings [94], polymer degradation was probably related to the elevated reaction temperatures. Thus, temperature and time should be carefully adjusted in order to preserve the polymer analytes. In addition, the SOM removal efficiency most likely depends on the composition of the examined soil. Iron(III) and manganese oxides, for instance, were indicated to catalyze the disproportionation of $\mathrm{H}_{2} \mathrm{O}_{2}$ into water and oxygen before an oxidation reaction was initiated [113]. Interactions with clay minerals, carbonate coatings, or occlusion in soil aggregates may further protect SOM from oxidation [114], which calls for more potent and selective SOM removal agents.

Fenton reagent, an acidified solution ( $\mathrm{pH} 3-5)$ of $\mathrm{H}_{2} \mathrm{O}_{2}$ and a $\mathrm{Fe}^{2+}$ catalyst, produces hydroxyl and hydroperoxyl radicals at high yields. Hydroxyl radicals are particularly effective in degrading SOM $\left(100 \pm 10 \%\right.$ removal efficiency) already at room temperature. Additional cooling $\left(\leq 40^{\circ} \mathrm{C}\right)$ is advisable since the reaction is extremely exothermic [94]. In contrast to treatments with $\mathrm{H}_{2} \mathrm{O}_{2}$ at elevated temperature, Hurley et al. [94] did not observe any detrimental effect on polymer sizes and masses after Fenton digestion, which may be attributed to the lower reaction temperatures $\left(\leq 40^{\circ} \mathrm{C}\right)$. This may further explain why Vermeiren et al. [106] only recovered 90\% PE after Fenton digestion of organic-rich sediments without monitoring the reaction temperature. Although promising, Fenton digestion has not yet been widely applied for soil sample preparations, but it should be further pursued.

Enzymatic digestion makes use of a variety of different enzymes for the selective degradation of potentially interfering matrix constituents without altering polymer analytes [69]. These enzymes include proteinase K [115], trypsin [116], lipase and amylase [117], corolase [118], protease, cellulase, and chitinase [31]. So far, no protocol on the enzymatic purification of soil samples for microplastic analysis has been published. Only a Swedish report by Sweden Water Research [119] lists commercial cellulase, esterase, and xylanases as enzymes potentially suitable for soil sample preparation, however, without reporting removal efficiencies or recovery rates. Enzymes targeting specific SOM constituents therefore still need to be investigated. However, even the enzymatic digestion of wastewater samples is often incomplete so that several enzymes need to be applied successively and in conjunction with oxidative treatments [31,108]. Such multi-step protocols may be costly and easily take more than two weeks per sample [31]. Furthermore, long and complicated sample preparation methods probably increase the risk of contamination, for instance, during additional filtering steps.

In terms of removal efficiencies and microplastic recoveries, oxidizing agents like Fenton reagent and $\mathrm{H}_{2} \mathrm{O}_{2}$ are currently considered the most suitable for SOM removal. However, biodegradable plastics and nanoplastics are still largely understudied and will require a reevaluation of sample preparation methods to avoid systematic underestimations. It is still not fully understood to what extent soil constituents like manganese oxides or clay minerals may interfere with oxidative techniques. Since most studies investigated agricultural soils, it is unclear if current methods are readily transferable to soils with a different SOM composition like chernozems or kastanozems. A thorough 
soil characterization, and thereby a better understanding of potential matrix interferences, may help the advancement of soil-specific sample preparation methods.

\subsection{Extraction with Organic Solvents}

In addition to density separation and SOM digestion, the use of organic solvents for the extraction of microplastics from solid matrices has gained growing attention within the scientific community (Table 3). Fabbri et al. [120] first extracted $1 \mathrm{mgg}^{-1}$ PVC and PS debris from beach sand with dichloromethane (DCM) using a Soxhlet apparatus. PVC recovery was $85 \%$ while PS was evaluated qualitatively. In recent years, further technical and analytical developments have lowered recoverable concentrations by a factor of $20-50[33,121,122]$ and made a broader spectrum of polymers amendable to extraction. Current methods not only include the commonly used polymers PE, PP, PS, PET, PC, and PMMA $[123,124]$ but also biodegradables like polybutylene sebacate (PBS) and PBAT $[125,126]$. In addition, methods have been simplified to batch extraction setups $[33,127]$ and automated to increase sample throughput and reproducibility, for example using accelerated solvent extraction (ASE) [123,124] or microwave-assisted extraction techniques [128].

What all these methods have in common is that they require the careful adjustment of extraction conditions, including the selection of an appropriate organic solvent, extraction temperature, and time, to enable quantitative dissolution or suspension of a predefined set of target polymers. While solvents like 1,2,4-trichlorobenzene (TCB) and xylenes have been shown to selectively dissolve polyolefins at temperatures between 120 and $140{ }^{\circ} \mathrm{C}[33,129]$, hexafluoroisopropanol (HFIP) already dissolves PET at $45^{\circ} \mathrm{C}$ [127]. Higher temperatures $\left(180^{\circ} \mathrm{C}\right)$ and pressures (up to $100 \mathrm{bar}$ ), as typically applied by ASE, broaden the analytical window. However, the harsher the extraction conditions get, the more likely it is that extracted polymers cannot be stabilized in solution when cooling down. This may be circumvented by precipitating the polymers in an inert matrix such as quartz sand for further sample processing [122]. Less selective extraction conditions may cause interferences from co-extracted matrix constituents [33], which need to be tackled by additional clean-up steps with methanol, Fenton oxidation, or density separation prior to polymer extraction [121,122]. In this respect, soil is a particularly challenging matrix for its diverse and heterogeneous nature. Humic acids, plant suberins and cutins, cellulose, and lignin are currently being discussed as main sources for interferences [33,122,124]. Steinmetz et al. [33] was able to link interferences with the quantification of PE to a soil organic carbon content exceeding $2.5 \%$, whereas Dierkes et al. [122] identified wood and leaf material as potential sources for interferences with PS and PE quantification, respectively. Both studies applied pyrolysis-gas chromatography/mass spectrometry (Py-GC/MS) after solvent extraction. By contrast, Peez et al. [121] suspected carbonates co-extracted from invertebrates with chloroform/trifluoroacetic acid (TFA) (Table 3) of interfering with PET analysis via quantitative nuclear magnetic resonance (NMR) spectroscopy. Sediments [121] and agricultural soil extracted for PBAT quantification [126] were not affected. Consequently, matrix interferences should be closely investigated for soil samples suspected to contain soil invertebrates. 
Table 3. Recoveries of various extraction methods with organic solvents from soil and other solid matrices.

\begin{tabular}{|c|c|c|c|c|c|c|c|c|c|c|}
\hline \multirow[t]{2}{*}{ Method } & \multicolumn{2}{|l|}{ Sample } & \multicolumn{2}{|l|}{ Polymer } & \multicolumn{3}{|c|}{ Extraction } & \multicolumn{2}{|r|}{ Recovery } & \multirow[t]{2}{*}{ Ref. } \\
\hline & Type & $\begin{array}{c}\text { Mass } \\
{[\mathrm{g}]}\end{array}$ & Type & $\begin{array}{l}\text { Spiked conc. } \\
{\left[\mathrm{mg} \mathrm{g}^{-1}\right]}\end{array}$ & Solvent(s) & $\begin{array}{c}\text { Volume } \\
{[\mathrm{mL}]}\end{array}$ & $\begin{array}{c}\text { Temperature } \\
{\left[{ }^{\circ} \mathrm{C}\right]}\end{array}$ & $\begin{array}{c}\text { Time } \\
{[\mathrm{h}]}\end{array}$ & {$[\%]$} & \\
\hline ASE & Municipal waste, soil & 2 & PE, PP, PS, PET, PVC & $5-25$ & DCM & 80 & 180 & 0.25 & $85-94$ & [123] \\
\hline ASE & Roadside and potting soil & 1 & PE, PP, PS & $0.05-0.75$ & THF & 35 & 185 & 1 & $77-123$ & [122] \\
\hline ASE & Agricultural soil & $2.5-5$ & PBAT & 1 & Chloroform/methanol (9:1) & $40-50$ & 120 & 0.5 & 100 & [126] \\
\hline ASE & Biosolids & 1 & PE, PP, PS, PET, PVC, PC, PMMA & $0.02-0.1$ & DCM & 80 & 180 & 0.25 & $85-128$ & [124] \\
\hline Batch extraction & Agricultural soil & 0.5 & PS & 5 & THF & 2 & 45 & 24 & 100 & [127] \\
\hline Batch extraction & Agricultural soil & 0.5 & PET & 20 & HFIP & 2 & 45 & 24 & 80 & [127] \\
\hline Batch extraction & Sediment & 2.5 & PET & 0.8 & Chloroform/TFA (4:1) & 1 & RT & $2-4$ & $91-108$ & [121] \\
\hline Batch extraction & Agricultural soil & 4 & PE, PP, PS & $0.05-0.25$ & $1,2,4-\mathrm{TCB}$ & 8 & 120 & 1 & $70-128$ & [33] \\
\hline Microwave & Beach sand & 1 & PS & 0.05 & $\mathrm{DCM}$ & 1 & 80 & 1 & 97 & [128] \\
\hline Kumagawa apparatus & Beach sand & 160 & PE, PS & $0.36-0.82$ & (1) DCM, (2) xylenes ${ }^{\dagger}$ & 90 & (1) 37, , (2) $135-140^{+}$ & $3-6$ & 95-97 & [129] \\
\hline Soxhlet & Sediment, suspended matter & 10 & PVC & 1 & DCM & 300 & $>40$ & 16 & 85 & [120] \\
\hline Soxhlet & Agricultural soil & 150 & PBS & 4 & Chloroform & NA & $>61$ & 8 & 83 & [125] \\
\hline
\end{tabular}

ASE = accelerated solvent extraction; DCM = dichloromethane; HFIP = hexafluoroisopropanol; TCB = trichlorobenzene; TFA = trifluoroacetic acid; THF = tetrahydrofurane.

${ }^{t}$ numbers in parentheses indicate sequential extraction steps. 


\subsection{Recent Developments}

The search for more robust and cost-effective, yet selective, sample preparation procedures for heterogeneous solid matrices has fueled further method development. Felsing et al. [130], for example, constructed an electrostatic separator that recovered $99 \%$ of microplastics from sandy substrates. However, the applicability of this approach was assumed to largely depend on the size distribution of microplastic particles and the texture of the investigated matrix [68]. If applied to soil, soil aggregates, SOM, and plant litter may further interfere with electrostatic interactions. Similarly, Grbic et al. [131] attempted to recover microplastics by magnetic extraction through the binding of iron nanoparticles to the microplastics' surface. However, matrix particles impeded the interaction of nanoparticles with microplastics, and microplastics fragmented during the separation procedure.

Another approach exploited the hydrophobicity of microplastics by recovering $>96 \%$ microplastics with canola oil [132]. In follow-up experiments, castor oil [133] and olive oil [134] were tested, obtaining recovery rates of $99 \%$ and $>90 \%$, respectively. Enders et al. [68] further suggested $n$-pentane as a preliminary cleanup step before matrix digestion to accelerate the sample preparation process. Although Scopetani et al. [134] emphasized that the distinct advantage of their method is its independence from polymer densities, Mani et al. [133] was unable to suspend PS particles from a fluvial solid matrix. Furthermore, the use of separation funnels led to clogging of the funnel outlet and, thus, impractical separation of water and oil. To circumvent this, Scopetani et al. [134] constructed cylinders made from polytetrafluoroethylene and froze the suspension to $-40{ }^{\circ} \mathrm{C}$ to decant the oil fraction. Further method refinement will be necessary to elaborate on the extraction of microplastics coated with SOM or biofilms that might hinder the contact between oil and polymer. An oxidative treatment may help to address this.

\section{Options for Subsequent Microplastic Quantification}

\subsection{Microscopy}

The analysis of larger plastic particles (mostly $>500 \mu \mathrm{m}$ ) is traditionally performed by manual selection under a stereomicroscope. The procedure enables the non-destructive determination of particle numbers, sizes, and shapes at low cost. The degree of sample preparation can be flexibly adjusted to the complexity of the matrix. Even more so than in aquatic samples, plastic recovery from soil varies with sample purity and the operator's knowledge of the particles' visual features [135-137]. For example, Corradini et al. [138] only considered plastic debris with "shiny surfaces, strong colors, and sharp geometrical shapes" after density separation of agricultural soil. Fibers with smooth sides and strong colors were classified as synthetic based on their visual appearance only. Additional fluorescent staining with Calcofluor white, Evans blue, and Nile red dyes may help to distinguish microplastics from the surrounding matrix $[139,140]$. Particularly in heterogeneous solid matrices such as soil, visual sorting for identification is expected to exhibit error rates of $20-70 \%$ [26] and should therefore be complemented with spectroscopic methods like FTIR with attenuated total reflection (ATR) or themoanalytical approaches [13].

\subsection{Spectroscopy}

FTIR and Raman (micro)spectroscopy permit the simultaneous analysis of chemical and physical properties of microplastics such as the polymer type, particle shapes and sizes down to a resolution of 20 and $1 \mu \mathrm{m}$, respectively (see Anger et al. [141] and Xu et al. [142] for comprehensive reviews on instrumental analytics). Both microspectroscopic techniques are commonly applied for particles $<500 \mu \mathrm{m}$ and require the sample to rest on a flat filter disc. With regard to typical disc diameters of $13-47 \mathrm{~mm}$, spatial measurement increments of several micrometers protract acquisition times and render complete filter scans nearly impossible. Instead, specific areas of interest are preselected manually by automated pattern recognition or by randomized subsampling [141,142]. Manual selection of suspected microplastic particles is particularly error-prone since white and transparent items may 
be easily missed on a bright filter background [143]. Even automated approaches may over- or underestimate particle counts when microplastics are unevenly distributed on the filter discs after sample preparation [141]. Error rates and measurement times may be decreased when using an FTIR microspectrometer with a focal plane array (FPA) where a grid of detector elements allows for chemical mapping of larger areas on the filter and may provide multiple measurements for the same particle [144]. However, even with FPA-FTIR microspectroscopy a single $47 \mathrm{~mm}$ filter may still take up to $10 \mathrm{~h}$ for acquisition [108]. Further challenges are associated with the sensitivity of FTIR and Raman microspectroscopy to interferences from water, atmospheric $\mathrm{CO}_{2}$, SOM, and concealment by clay particles that require rigorous matrix removal during sample preparation [141,142]. Although crucial for the determination of particle morphologies, the time-consuming measurements might still restrict the applicability of microspectroscopic methods for the analysis of microplastics in soil, particularly for screening and monitoring studies.

\subsection{Thermoanalysis}

It has been been continuously argued that microplastic mass contents are more robust and better suited to interstudy comparisons and modeling than particle counts. That may be because microplastic masses are often less affected by the sample treatment and less prone to bias from size selectivity $[24,144]$. The non-uniform distribution of particles shapes, sizes, and densities in environmental samples further challenges a reliable extrapolation from particles sizes and densities to particle masses [24]. Therefore, a range of mass-sensitive thermoanalytical methods is increasingly applied complementary or in conjunction with FTIR and Raman imaging. These methods include thermogravimetry (TGA) [145,146], thermoextraction and desorption (TED) [147], and pyrolysis (Py) coupled with GC/MS [32,148]. For an extensive review on thermoanalytical techniques, we refer to Nasa et al. [149].

As thermoanalysis is based on the thermal decomposition of the polymer analyte at temperatures $>500{ }^{\circ} \mathrm{C}$ and quantification via characteristic pyrolysis products, determination of the particle size and morphology is impossible if not done in advance $[147,150]$. With recent method refinements $[33,122]$ and novel hyphenations of thermoanalytical sample introduction with FTIR or time-of-flight (TOF) detectors [151], instrumental analytics have become sufficiently sensitive for the quantification of microplastics in the low $\mathrm{mg} \mathrm{kg}^{-1}$ to $\mu \mathrm{gg}^{-1}$ range. A recent interlaboratory comparison of thermoanalytical methods further showed that thermoanalytical setups involving chromatographical separation were able to reliably identify and quantify PE, PP, PS, and PET in an organic sediment [152]. TGA/MS proved itself particularly useful for the assessment of total polymer contents. Method harmonization and interlaboratory reproducibility were identified as crucial points. If microplastics are not extracted with organic solvents (see Section 3.6), one major challenge of applying thermoanalytical techniques to soil is the preparation of a homogeneous aliquot of less than $100 \mathrm{mg}$ for sample introduction. This typically requires cryomilling and a very sensitive microscale to maintain sufficient measurement repeatability [33,122]. Furthermore, interferences may occur when pyrolysis products in plastic and matrix are identical. This may particularly apply to lignins interfering with PS quantification [32] and lipids and waxes from plant cuticles leading to a false-positive detection of PE [33]. As discussed in Section 3.7, further research will be needed to scrutinize the sources of matrix interferences in soil for the advancement of analytical methods for microplastic analysis.

\subsection{Further Techniques}

In the last few years, well-established liquid chromatographical (LC) methods like LC/MS [153], size-exclusion chromatography (SEC), and gel permeation chromatography (GPC) [127] have been rediscovered for microplastic analysis (see Drzeżdżon et al. [154] for an extensive review on alternative, less established methods for microplastic analysis). Although particularly sensitive and highly reproducible, LC/MS is restricted to polymers like PS that are readily soluble in organic eluents at room temperature [153]. By contrast, high-temperature GPC and SEC systems are able to analyze 
a wide range of different polymers and provide additional information on the polymer's molecular weight, but their UV and refractive detectors typically require polymer concentrations in the $\mathrm{mg} \mathrm{mL}^{-1}$ range [127]. Their applicability for real-world soil samples may thus be limited, and interferences from soil constituents may be more likely.

Another promising new technique is quantitative NMR spectroscopy initially developed by Peez et al. [121] for the quantification of PET in environmental samples. Furthermore, PE and PS [155], PVC, ABS, and PA [156], as well as PBS and PBAT [126] have been shown to be amenable to this approach. Limits of detection are currently in the low $\mathrm{mg} \mathrm{kg}^{-1}$ range. Matrix interferences from sediment [121] and agricultural soil [126] were negligible if samples were oxidatively pretreated or extracted via ASE, respectively. Similar to LC, however, quantitative NMR spectroscopy requires the polymers to be dissolved in an appropriate solvent prior to analysis, as outlined in Section 3.6. The use of deuterated solvents reduces the NMR background noise but may easily increase solvent costs by a factor of 1000. In addition, the solubility of polymers in organic solvents is often specific so that the analysis of polymer mixtures needs to be performed for each polymer or certain subgroups separately.

Further noteworthy approaches include electron microscopy with energy-dispersive X-ray spectroscopy [157], TOF-secondary ion mass spectrometry [158], and near-infrared (NIR) spectroscopy $[138,159]$. The methods enable fast, qualitative screenings of microplastic particles and surface characteristics after oxidative treatment or density separation. Quantifying PE, PET, and PVC via NIR, however, only yielded limits of detection in the lower $\mathrm{g} \mathrm{kg}^{-1}$ range, which may be suitable for identifying microplastic hotspots in soils near point sources, but not applicable to more diffuse pollution scenarios. Moreover, the interpretation of NIR spectra is complicated and depends strongly on the soil matrix [138], which calls for further method development.

\section{Suggestions for Best-Practice Sample Preparation}

Figure 1 summarizes state-of-the-art preparation methods for microplastic analysis of soil samples and suggests best practices. Current research on microplastics in terrestrial and soil systems provides limited information on the study area, soil, and sampling procedure. Based on established soil sampling guidelines, future studies are suggested to implement representative sampling schemes involving a sufficient number of composite samples for a given sampling area (Section 2.1). Sample quantities should be $>500 \mathrm{~g}$ to acknowledge the heterogeneous distribution of microplastic particles in soil. Total sample quantities may need to be negotiated with local farmers or land owners to assure sustainable management of soil resources. Local stakeholders can further help to obtain valuable information on site geomorphology, land use history, and agricultural management practices. As a complement, the studied soil should at least be characterized for its texture, SOM content, and carbonate content to enable an informed assessment of microplastic recoveries and interstudy comparisons (Section 2.2). 


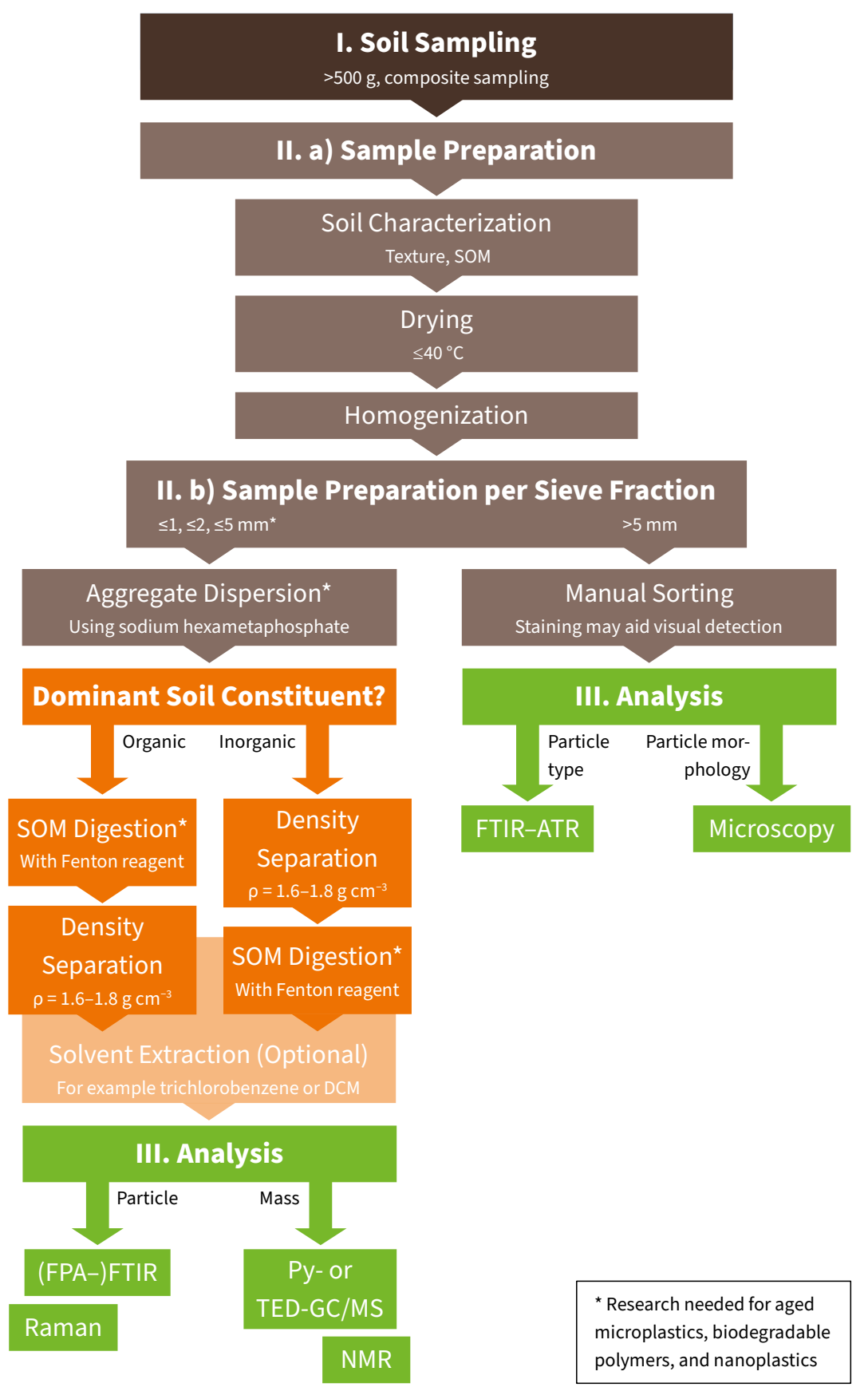

Figure 1. Suggestions for best-practice sample preparation for microplastic analysis of soil.

Sample preparation involves drying below $60^{\circ} \mathrm{C}$, ideally $\leq 40^{\circ} \mathrm{C}$, to avoid any deterioration of microplastic particles (Section 3.1). This may be particularly important for preserving biodegradable polymers. Whether freeze drying might fragment microplastics by frost wedging is unknown to date. After sufficient homogenization, soil should be sieved to 1,2, and $5 \mathrm{~mm}$ to comply both with established soil texture classifications and microplastic definitions (Section 3.2). Further sample preparation is performed per sieve fraction. While manual sorting of macroplastics often suffices for the sieve fraction $>5 \mathrm{~mm}$, finer fractions $(\leq 1, \leq 2$, and $\leq 5 \mathrm{~mm})$ may require dispersing soil aggregates to retrieve occluded microplastics (Section 3.3). However, it still needs to be assessed whether soil sieving and dispersion methods like agitation with sodium hexametaphosphate solution or ultrasonication may fragment aged or biodegradable microplastics as well as nanoplastics. 
If inorganic minerals are dominant in the investigated soil, the microplastic fraction should be preconcentrated by density separation (Section 3.4). Selecting a specific density separation setup involves careful consideration of the targeted polymers and particle sizes, recoveries, cost efficiency, ease of operation, and environmental concerns. To extract all major polymer types, aiming for determination of total plastic contents in soil, high-density solutions $\left(\rho=1.6-1.8 \mathrm{~g} \mathrm{~cm}^{-3}\right)$ such as $\mathrm{NaBr}$ or SPT are recommended. Solutions with lower densities like saturated $\mathrm{NaCl}$ solution may be useful for target analyses, particularly of PE, PP, and PS. In any case, separation methods should be validated by recovery experiments that involve spiking known polymer types and particle sizes to a realistic, well-characterized soil matrix. In addition, potential sources of contamination need to be closely monitored, for instance, by using procedural blanks and closed containers. In this respect, separation funnels may be a promising alternative to open vessels that are currently the most common equipment for microplastic separation.

Additional SOM removal (Section 3.5) is necessary if analytical interferences from SOM are expected. Ideally, SOM removal agents should efficiently digest or degrade SOM while preserving microplastic analytes. Current literature recommends Fenton reagent, which allows for efficient SOM oxidation at controlled temperatures $\left(\leq 40^{\circ} \mathrm{C}\right)$ and thus has minimal impact on microplastics. An alternative may be selective extraction of polymers in organic solvents like DCM or 1,2,4-TCB at elevated temperature (Section 3.6) while keeping interfering SOM in the precipitate. By doing this, physical properties of the particles will be lost. Nonetheless, such approaches may become increasingly relevant due to the growing demand for quantitative methods for biodegradable plastics, which are more sensitive to degradation during sample preparation than conventional polymers.

The major options for subsequent microplastic analysis are visual microscopy for particles $>500 \mu \mathrm{m}$ (Section 4.1), FTIR or Raman (micro)spectroscopy for smaller particles (Section 4.2), mass-based, thermoanalytical methods (Section 4.3), and quantitative NMR spectroscopy (Section 4.4). If particle numbers, sizes, and morphology are of specific interest to the research question, spectroscopic methods are favorable. For quantifying plastic pollution in terms of mass, which has been argued to be more comparable, thermoanalytical methods and NMR spectroscopy may be preferred. The associated limits of detection in terms of microplastic size need to be stated, also taking previous sample preparation steps into account.

Terrestrial microplastics research is a quickly evolving field characterized by an extraordinarily high diversity of newly developed or refined analytical approaches. While this challenges future standardization, active method development offers great opportunities for innovations and microplastic analyses tailored to specific research questions. However, harmonization needs to start with uniform communication of microplastic quantities in particles $\mathrm{kg}^{-1}$ for microplastic counts and in $\mu \mathrm{g}$ or $\mathrm{g} \mathrm{kg}^{-1}$ for mass-based results [24]. Furthermore, quality control measures should be implemented at an early stage of method development. This includes (1) controlling contamination by working plastic-free and including blank measurements, (2) thorough documentation of the studied soil, sample preparation, and analytical methods, and (3) method validation with recovery tests and an assessment of analytical limitations. In this respect, best practices for terrestrial microplastic analysis still need to be established. Because of the complexity and heterogeneity of soil, soil sample preparation for microplastic analysis must be adapted to the specific properties and composition of the examined soil. This will not only help to ensure efficient matrix removal while conserving microplastics, it will also advance the field towards a better understanding of processes and interactions of microplastic particles with SOM and other soil constituents.

Author Contributions: Conceptualization, D.T., B.S. and Z.S.; methodology, D.T., B.S., W.M.H. and Z.S.; writing—original draft preparation, D.T., B.S., W.M.H. and Z.S.; writing—review \& editing, D.T., B.S., W.M.H. and Z.S.; supervision, Z.S. All authors have read and agreed to the published version of the manuscript.

Funding: This work was funded by ACEnano (EU Horizon 2020, grant agreement no. 720952), the Swedish research council FORMAS (project no. 2018-01080), and the Open Access Publication Fund at University Koblenz-Landau. 
Acknowledgments: We kindly thank Gabriele E. Schaumann, Aaron Kintzi, and Paul Löffler for their valuable feedback on the manuscript. Furthermore, we thank Wendy Höpp for English editing and Mareike Zech for the graphic design.

Conflicts of Interest: The authors declare no competing conflicts of interest.

\section{Abbreviations}

The following abbreviations are used in this manuscript:

$\begin{array}{ll}\text { ABS } & \text { acrylonitrile butadiene styrene } \\ \text { ASE } & \text { accelerated solvent extraction } \\ \text { ATR } & \text { attenuated total reflection } \\ \text { DCM } & \text { dichloromethane } \\ \text { EVA } & \text { ethylene-vinyl acetate } \\ \text { FTIR } & \text { Fourier transformed infrared } \\ \text { FPA } & \text { focal plane array } \\ \text { GC } & \text { gas chromatography } \\ \text { GPC } & \text { gel permeation chromatography } \\ \text { HFIP } & \text { hexafluoroisopropanol } \\ \text { LC } & \text { liquid chromatographical } \\ \text { MS } & \text { mass spectrometry } \\ \text { NIR } & \text { near-infrared } \\ \text { NMR } & \text { nuclear magnetic resonance } \\ \text { PA } & \text { polyamide } \\ \text { PBAT } & \text { polybutylene adipate terephthalate } \\ \text { PBS } & \text { polybutylene sebacate } \\ \text { PC } & \text { polycarbonate } \\ \text { PE } & \text { polyethylene } \\ \text { PET } & \text { polyethylene terephthalate } \\ \text { PLA } & \text { polylactic acid } \\ \text { PMMA } & \text { poly(methyl methacrylate) } \\ \text { PP } & \text { polypropylene } \\ \text { PU } & \text { polyurethane } \\ \text { PS } & \text { polystyrene } \\ \text { PVC } & \text { polyvinyl chloride } \\ \text { PU } & \text { polyurethane } \\ \text { Py } & \text { pyrolysis } \\ \text { SEC } & \text { size-exclusion chromatography } \\ \text { SOM } & \text { soil organic matter } \\ \text { SPT } & \text { sodium polytungstate } \\ \text { TED } & \text { thermoextraction and desorption } \\ \text { TFA } & \text { trifluoroacetic acid } \\ \text { TGA } & \text { thermogravimetry } \\ \text { THF } & \text { tetrahydrofurane } \\ \text { TCB } & \text { trichlorobenzene } \\ \text { TOF } & \text { time-of-flight } \\ & \end{array}$

\section{References}

1. Geyer, R.; Jambeck, J.R.; Law, K.L. Production, use, and fate of all plastics ever made. Sci. Adv. 2017, 3, e1700782. [CrossRef] [PubMed]

2. Kawecki, D.; Nowack, B. Polymer-Specific Modeling of the Environmental Emissions of Seven Commodity Plastics As Macro- and Microplastics. Environ. Sci. Technol. 2019, 53, 9664-9676. [CrossRef] [PubMed]

3. PlasticsEurope. Plastics-The Facts 2019: An Analysis of European Plastics Production, Demand and Waste Data; PlasticsEurope: Brussels, Belgium, 2019.

4. Burgstaller, M.; Potrykus, A.; Weißenbacher, J.; Kabasci, D.S.; Merrettig-Bruns, D.U.; Sayder, B. Study on the Treatment of Biodegradable Plastics; Technical Report; Umweltbundesamt: Dessau, Germany, 2018.

5. Thompson, R.C. Plastic Debris in the Marine Environment: Consequences and Solutions; Technical Report; Marine Nature Conservation in Europe: Stralsund, Germany, 2006. 
6. Horton, A.A.; Svendsen, C.; Williams, R.J.; Spurgeon, D.J.; Lahive, E. Large microplastic particles in sediments of tributaries of the River Thames UK-Abundance, sources and methods for effective quantification. Mar. Pollut. Bull. 2017, 114, 218-226. [CrossRef] [PubMed]

7. De Souza Machado, A.A.; Lau, C.W.; Kloas, W.; Bergmann, J.; Bachelier, J.B.; Faltin, E.; Becker, R.; Görlich, A.S.; Rillig, M.C. Microplastics Can Change Soil Properties and Affect Plant Performance. Environ. Sci. Technol. 2019, 53, 6044-6052. [CrossRef] [PubMed]

8. De Souza Machado, A.A.; Horton, A.A.; Davis, T.; Maaß, S. Microplastics and Their Effects on Soil Function as a Life-Supporting System. In Microplastics in Terrestrial Environments: Emerging Contaminants and Major Challenges; He, D., Luo, Y., Eds.; The Handbook of Environmental Chemistry, Springer International Publishing: Cham, Switzerland, 2020; pp. 199-222. [CrossRef]

9. Boots, B.; Russell, C.W.; Green, D.S. Effects of Microplastics in Soil Ecosystems: Above and Below Ground. Environ. Sci. Technol. 2019, 53, 11496-11506. [CrossRef] [PubMed]

10. Lei, L.; Liu, M.; Song, Y.; Lu, S.; Hu, J.; Cao, C.; Xie, B.; Shi, H.; He, D. Polystyrene (nano)microplastics cause size-dependent neurotoxicity, oxidative damage and other adverse effects in Caenorhabditis elegans. Environ. Sci. Nano 2018, 5, 2009-2020. [CrossRef]

11. Rillig, M.C.; Lehmann, A.; Machado, A.A.d.S.; Yang, G. Microplastic Effects on Plants. New Phytol. 2019, 223, 1066-1070. [CrossRef]

12. Büks, F.; Loes van Schaik, N.; Kaupenjohann, M. What Do We Know about How the Terrestrial Multicellular Soil Fauna Reacts to Microplastic? SOIL 2020, 6, 245-267. [CrossRef]

13. He, D.; Luo, Y.; Lu, S.; Liu, M.; Song, Y.; Lei, L. Microplastics in soils: Analytical methods pollution characteristics and ecological risks. TrAC Trends Anal. Chem. 2018, 109, 163-172. [CrossRef]

14. Hurley, R.R.; Nizzetto, L. Fate and occurrence of micro(nano)plastics in soils: Knowledge gaps and possible risks. Curr. Opin. Environ. Sci. Health 2018, 1, 6-11. [CrossRef]

15. Wang, J.; Liu, X.; Li, Y.; Powell, T.; Wang, X.; Wang, G.; Zhang, P. Microplastics as contaminants in the soil environment: A mini-review. Sci. Total Environ. 2019, 691, 848-857. [CrossRef]

16. Steinmetz, Z.; Wollmann, C.; Schaefer, M.; Buchmann, C.; David, J.; Tröger, J.; Muñoz, K.; Frör, O.; Schaumann, G.E. Plastic mulching in agriculture. Trading short-term agronomic benefits for long-term soil degradation? Sci. Total Environ. 2016, 550, 690-705. [CrossRef]

17. Bianco, A.; Passananti, M. Atmospheric Micro and Nanoplastics: An Enormous Microscopic Problem. Sustainability 2020, 12, 7327. [CrossRef]

18. Bergmann, M.; Mützel, S.; Primpke, S.; Tekman, M.; Trachsel, J.; Gerdts, G. White and wonderful? Microplastics prevail in snow from the Alps to the Arctic. Sci. Adv. 2019, 5, eaax1157. [CrossRef] [PubMed]

19. Huerta Lwanga, E.; Gertsen, H.; Gooren, H.; Peters, P.; Salánki, T.; van der Ploeg, M.; Besseling, E.; Koelmans, A.A.; Geissen, V. Incorporation of microplastics from litter into burrows of Lumbricus terrestris. Environ. Pollut. 2017, 220, 523-531. [CrossRef] [PubMed]

20. Rillig, M.C.; Ziersch, L.; Hempel, S. Microplastic transport in soil by earthworms. Sci. Rep. 2017, 7, 1362. [CrossRef]

21. Van den Berg, P.; Huerta-Lwanga, E.; Corradini, F.; Geissen, V. Sewage sludge application as a vehicle for microplastics in eastern Spanish agricultural soils. Environ. Pollut. 2020, 261, 114198. [CrossRef]

22. Briassoulis, D.; Babou, E.; Hiskakis, M.; Kyrikou, I. Analysis of long-term degradation behaviour of polyethylene mulching films with pro-oxidants under real cultivation and soil burial conditions. Environ. Sci. Pollut. Res. Int. 2015, 22, 2584-2598. [CrossRef]

23. Cai, L.; Wang, J.; Peng, J.; Wu, Z.; Tan, X. Observation of the degradation of three types of plastic pellets exposed to UV irradiation in three different environments. Sci. Total Environ. 2018, 628-629, 740-747. [CrossRef]

24. Braun, U.; Jekel, M.; Gerdts, G.; Ivleva, N.P.; Reiber, J. Microplastics Analytics—Sampling, Preparation and Detection Methods; Bundesministerium für Bildung und Forschung: Berlin, Germany, 2018.

25. Hartmann, N.; Hüffer, T.; Thompson, R.; Hassellöv, M.; Verschoor, A.; Daugaard, A.; Rist, S.; Karlsson, T.; Brennholt, N.; Cole, M.; et al. Are We Speaking the Same Language? Recommendations for a Definition and Categorization Framework for Plastic Debris. Environ. Sci. Technol. 2019, 53, 1039-1047. [CrossRef]

26. Bläsing, M.; Amelung, W. Plastics in soil: Analytical methods and possible sources. Sci. Total Environ. 2018, 612, 422-435. [CrossRef] [PubMed] 
27. Möller, J.N.; Löder, M.G.J.; Laforsch, C. Finding Microplastics in Soils: A Review of Analytical Methods. Environ. Sci. Technol. 2020, 54, 2078-2090. [CrossRef] [PubMed]

28. Dioses-Salinas, D.C.; Pizarro-Ortega, C.I.; la Torre, G.E.D. A methodological approach of the current literature on microplastic contamination in terrestrial environments: Current knowledge and baseline considerations. Sci. Total Environ. 2020, 730, 139164. [CrossRef] [PubMed]

29. Blume, H.P.; Brümmer, G.W.; Fleige, H.; Horn, R.; Kandeler, E.; Kögel-Knabner, I.; Kretzschmar, R.; Stahr, K.; Wilke, B.M. Scheffer/Schachtschabel Soil Science, 1st ed.; Springer: Berlin, Germany, 2016.

30. Bronick, C.; Lal, R. Soil structure and management: A review. Geoderma 2005, 124, 3-22. [CrossRef]

31. Löder, M.G.J.; Imhof, H.K.; Ladehoff, M.; Löschel, L.A.; Lorenz, C.; Mintenig, S.; Piehl, S.; Primpke, S.; Schrank, I.; Laforsch, C.; et al. Enzymatic Purification of Microplastics in Environmental Samples. Environ. Sci. Technol. 2017, 51, 14283-14292. [CrossRef]

32. Fischer, M.; Scholz-Böttcher, B.M. Simultaneous Trace Identification and Quantification of Common Types of Microplastics in Environmental Samples by Pyrolysis-Gas Chromatography-Mass Spectrometry. Environ. Sci. Technol. 2017, 51, 5052-5060. [CrossRef]

33. Steinmetz, Z.; Kintzi, A.; Muñoz, K.; Schaumann, G.E. A simple method for the selective quantification of polyethylene polypropylene, and polystyrene plastic debris in soil by pyrolysis-gas chromatography/mass spectrometry. J. Anal. Appl. Pyrolysis 2020, 147, 104803. [CrossRef]

34. Fojt, J.; David, J.; Přikryl, R.; Řezáčová, V.; Kučerík, J. A critical review of the overlooked challenge of determining micro-bioplastics in soil. Sci. Total Environ. 2020, 745, 140975. [CrossRef]

35. Wang, Z.; Taylor, S.E.; Sharma, P.; Flury, M. Poor extraction efficiencies of polystyrene nano- and microplastics from biosolids and soil. PLoS ONE 2018, 13, e0208009. [CrossRef]

36. Wahl, A.; Le Juge, C.; Davranche, M.; El Hadri, H.; Grassl, B.; Reynaud, S.; Gigault, J. Nanoplastic Occurrence in a Soil Amended with Plastic Debris. Chemosphere 2020, 262, 127784. [CrossRef]

37. Zhu, F.; Zhu, C.; Wang, C.; Gu, C. Occurrence and Ecological Impacts of Microplastics in Soil Systems: A Review. Bull. Environ. Contam. Toxicol. 2019, 102, 741-749. [CrossRef] [PubMed]

38. Wu, M.; Yang, C.; Du, C.; Liu, H. Microplastics in waters and soils: Occurrence analytical methods and ecotoxicological effects. Ecotoxicol. Environ. Saf. 2020, 202, 110910. [CrossRef]

39. Meixner, K.; Kubiczek, M.; Fritz, I. Microplastic in soil-current status in Europe with special focus on method tests with Austrian samples. AIMS Environ. Sci. 2020, 7, 174-191. [CrossRef]

40. ISO 18400-102. Soil Quality-Sampling-Part 102: Selection and Application of Sampling Techniques; Technical Report; International Organization for Standardization: Geneva, Switzerland, 2017.

41. Piehl, S.; Leibner, A.; Löder, M.G.J.; Dris, R.; Bogner, C.; Laforsch, C. Identification and quantification of macro- and microplastics on an agricultural farmland. Sci. Rep. 2018, 8, 1-9. [CrossRef]

42. Corradini, F.; Meza, P.; Eguiluz, R.; Casado, F.; Huerta-Lwanga, E.; Geissen, V. Evidence of microplastic accumulation in agricultural soils from sewage sludge disposal. Sci. Total Environ. 2019, 671, 411-420. [CrossRef]

43. Sponagel, H.; Grottenthaler, W.; Hartmann, K.; Hartwich, R.; Janetzko, P.; Joisten, H.; Kühn, D.; Sabel, K.; Traidl, R. Bodenkundliche Kartieranleitung, 5th ed.; Schweizerbart: Stuttgart, Germany, 2005.

44. BBodSchV. Federal Soil Protection and Contaminated Sites Ordinance; Number On the Basis of $\S \S 6,8$ Paragraphs 1 and 2 and $\S 13$ Paragraph 1 Sentence 2 Federal Soil Protection Law of 17 March 1998 (Federal Law Gazette I p. 502); Bundesgesetzblatt: Berlin, Germany, 1999.

45. Liu, M.; Lu, S.; Song, Y.; Lei, L.; Hu, J.; Lv, W.; Zhou, W.; Cao, C.; Shi, H.; Yang, X.; et al. Microplastic and mesoplastic pollution in farmland soils in suburbs of Shanghai, China. Environ. Pollut. 2018, 242, 855-862. [CrossRef]

46. Schoeneberger, P.; Wysocki, D.; Benham, E.; Staff, S.S. Field Book for Describing and Sampling Soils, Version 3.0; Natural Resources Conservation Service, National Soil Survey Center: Lincoln, NE, USA, 2012.

47. EPA, U. LSASD Operating Procedure for Soil Sampling; Technical Report LSASDPROC-300-R4; Laboratory Services and Applied Science Division: Athens, GA, USA, 2020.

48. Scheurer, M.; Bigalke, M. Microplastics in Swiss Floodplain Soils. Environ. Sci. Technol. 2018, 52, 3591-3598. [CrossRef]

49. Witzig, C.S.; Földi, C.; Wörle, K.; Habermehl, P.; Pittroff, M.; Müller, Y.K.; Lauschke, T.; Fiener, P.; Dierkes, G.; Freier, K.; et al. When Good Intentions Go Bad-False Positive Microplastic Detection Caused by Disposable Gloves. Environ. Sci. Technol. 2020. [CrossRef] 
50. Ramos, L.; Berenstein, G.; Hughes, E.A.; Zalts, A.; Montserrat, J.M. Polyethylene film incorporation into the horticultural soil of small periurban production units in Argentina. Sci. Total Environ. 2015, 523, 74-81. [CrossRef]

51. Huerta Lwanga, E.; Vega, J.M.; Quej, V.K.; Chi Angeles, J.D.; Cid, L.S.D.; Chi, C.; Segura, G.E.; Gertsen, H.; Salánki, T.; van der Ploeg, M.; et al. Field evidence for transfer of plastic debris along a terrestrial food chain. Sci. Rep. 2017, 7, 1-7. [CrossRef]

52. ISO 17892-4. Geotechnical Investigation and Testing_Laboratory Testing of Soil_Part 4: Determination of Particle Size Distribution; Technical report; International Organization for Standardization: Geneva, Switzerland, 2016.

53. Hammersley, J.M. Stochastic Models for the Distribution of Particles in Space. Adv. Appl. Probab. 1972, 4, 47. [CrossRef]

54. ISO 11277. Soil Quality—Determination of Particle Size Distribution in Mineral Soil Material—Method by Sieving and Sedimentation; Technical Report; International Organization for Standardization: Geneva, Switzerland, 2020.

55. ISO 11272. Soil Quality—Determination of Dry Bulk Density; Technical Report; International Organization for Standardization: Geneva, Switzerland, 2017.

56. DIN EN 15935. Sludge, Treated Biowaste, Soil And Waste-Determination of Loss on Ignition; Technical Report; Beuth: Berlin, Germany, 2020. [CrossRef]

57. Zhang, S.; Yang, X.; Gertsen, H.; Peters, P.; Salánki, T.; Geissen, V. A simple method for the extraction and identification of light density microplastics from soil. Sci. Total. Environ. 2018, 616-617, 1056-1065. [CrossRef] [PubMed]

58. ISO 11464. Soil Quality_Pretreatment of Samples for Physico-Chemical Analysis; Technical report; International Organization for Standardization: Geneva, Switzerland, 2006.

59. Beyler, C.; Hirschler, M. Thermal Decomposition of Polymers. In SFPE Handbook of Fire Protection Engineering; DiNenno, P.J., Ed.; National Fire Protection Association: Quincy, MA, USA, 2002; Volume 2.

60. Enders, K.; Lenz, R.; Ivar do Sul, J.A.; Tagg, A.S.; Labrenz, M. When every particle matters: A QuEChERS approach to extract microplastics from environmental samples. MethodsX 2020, 7, 100784. [CrossRef]

61. Zubris, K.A.V.; Richards, B.K. Synthetic fibers as an indicator of land application of sludge. Environ. Pollut. 2005, 138, 201-211. [CrossRef] [PubMed]

62. Huang, Y.; Liu, Q.; Jia, W.; Yan, C.; Wang, J. Agricultural plastic mulching as a source of microplastics in the terrestrial environment. Environ. Pollut. 2020, 260, 114096. [CrossRef]

63. Zhou, B.; Wang, J.; Zhang, H.; Shi, H.; Fei, Y.; Huang, S.; Tong, Y.; Wen, D.; Luo, Y.; Barceló, D. Microplastics in agricultural soils on the coastal plain of Hangzhou Bay, east China: Multiple sources other than plastic mulching film. J. Hazard. Mater. 2020, 388, 121814. [CrossRef]

64. Garcés-Ordóñez, O.; Castillo-Olaya, V.A.; Granados-Briceño, A.F.; García, L.M.B.; Díaz, L.F.E. Marine litter and microplastic pollution on mangrove soils of the Ciénaga Grande de Santa Marta, Colombian Caribbean. Mar. Pollut. Bull. 2019, 145, 455-462. [CrossRef]

65. Vermaire, J.C.; Pomeroy, C.; Herczegh, S.M.; Haggart, O.; Murphy, M. Microplastic abundance and distribution in the open water and sediment of the Ottawa River, Canada, and its tributaries. FACETS 2017, 2, 301-314. [CrossRef]

66. Zhang, G.S.; Liu, Y.F. The distribution of microplastics in soil aggregate fractions in southwestern China. Sci. Total Environ. 2018, 642, 12-20. [CrossRef]

67. Cerli, C.; Celi, L.; Kalbitz, K.; Guggenberger, G.; Kaiser, K. Separation of light and heavy organic matter fractions in soil-Testing for proper density cut-off and dispersion level. Geoderma 2012, 170, 403-416. [CrossRef]

68. Enders, K.; Tagg, A.S.; Labrenz, M. Evaluation of Electrostatic Separation of Microplastics From Mineral-Rich Environmental Samples. Front. Environ. Sci. 2020, 8. [CrossRef]

69. Liu, M.; Lu, S.; Chen, Y.; Cao, C.; Bigalke, M.; He, D. Analytical Methods for Microplastics in Environments: Current Advances and Challenges. In The Handbook of Environmental Chemistry; Springer International Publishing: Cham, Switzerland, 2020; pp. 3-24._2019_436. [CrossRef]

70. Chen, Y.; Leng, Y.; Liu, X.; Wang, J. Microplastic pollution in vegetable farmlands of suburb Wuhan, central China. Environ. Pollut. 2020, 257, 113449. [CrossRef] [PubMed] 
71. Herrera, A.; Garrido-Amador, P.; Martínez, I.; Samper, M.D.; López-Martínez, J.; Gómez, M.; Packard, T.T. Novel methodology to isolate microplastics from vegetal-rich samples. Mar. Pollut. Bull. 2018, 129, 61-69. [CrossRef] [PubMed]

72. Nuelle, M.T.; Dekiff, J.H.; Remy, D.; Fries, E. A new analytical approach for monitoring microplastics in marine sediments. Environ. Pollut. 2014, 184, 161-169. [CrossRef]

73. Liu, M.; Song, Y.; Lu, S.; Qiu, R.; Hu, J.; Li, X.; Bigalke, M.; Shi, H.; He, D. A method for extracting soil microplastics through circulation of sodium bromide solutions. Sci. Total Environ. 2019, 691, 341-347. [CrossRef] [PubMed]

74. Quinn, B.; Murphy, F.; Ewins, C. Validation of density separation for the rapid recovery of microplastics from sediment. Anal. Methods 2017, 9, 1491-1498. [CrossRef]

75. Xiong, X.; Zhang, K.; Chen, X.; Shi, H.; Luo, Z.; Wu, C. Sources and distribution of microplastics in China's largest inland lake-Qinghai Lake. Environ. Pollut 2018, 235, 899-906. [CrossRef]

76. Claessens, M.; van Cauwenberghe, L.; Vandegehuchte, M.B.; Janssen, C.R. New techniques for the detection of microplastics in sediments and field collected organisms. Mar. Pollut. Bull. 2013, 70, 227-233. [CrossRef]

77. Frère, L.; Paul-Pont, I.; Rinnert, E.; Petton, S.; Jaffré, J.; Bihannic, I.; Soudant, P.; Lambert, C.; Huvet, A. Influence of environmental and anthropogenic factors on the composition concentration and spatial distribution of microplastics: A case study of the Bay of Brest (Brittany, France). Environ. Pollut. 2017, 225, 211-222. [CrossRef]

78. Frias, J.; Pagter, E.; Nash, R.; O’Connor, I.; Carretero, O.; Filgueiras, A.; Viñas, L.; Gago, J.; Antunes, J.; Bessa, F.; et al. Standardised Protocol for Monitoring Microplastics in Sediments; Technical Report; JPI-Oceans BASEMAN: Brussels, Belgium, 2018.

79. Campanale, C.; Savino, I.; Pojar, I.; Massarelli, C.; Uricchio, V.F. A Practical Overview of Methodologies for Sampling and Analysis of Microplastics in Riverine Environments. Sustainability 2020, 12, 6755. [CrossRef]

80. Masura, J.; Baker, J.; Foster, G.; Arthur, C. Laboratory Methods for the Analysis of Microplastics in the Marine Environment: Recommendations for Quantifying Snythetic Particles in Waters and Sediment. NOAA Technical Memorandum. NOS-ORER-48; Technical report; National Oceanic and Atmospheric Administration: Washington, DC, USA, 2015.

81. Renner, G.; Nellessen, A.; Schwiers, A.; Wenzel, M.; Schmidt, T.C.; Schram, J. Hydrophobicity-Water/Air-Based Enrichment Cell for Microplastics Analysis within Environmental Samples: A Proof of Concept. MethodsX 2019. [CrossRef]

82. Van Cauwenberghe, L.; Devriese, L.; Galgani, F.; Robbens, J.; Janssen, C.R. Microplastics in Sediments: A Review of Techniques, Occurrence and Effects. Mar. Environ. Res. 2015, 111, 5-17. [CrossRef] [PubMed]

83. Stolte, A.; Forster, S.; Gerdts, G.; Schubert, H. Microplastic concentrations in beach sediments along the German Baltic coast. Mar. Pollut. Bull. 2015, 99, 216-229. [CrossRef]

84. Stock, F.; Kochleus, C.; Bänsch-Baltruschat, B.; Brennholt, N.; Reifferscheid, G. Sampling techniques and preparation methods for microplastic analyses in the aquatic environment-A review. TrAC Trends Anal. Chem. 2019, 113, 84-92. [CrossRef]

85. ECHA. Potassium Formate; Technical Report 209-677-9; European Chemicals Agency: Helsinki, Finnland, 2020.

86. Mahon, A.M.; O'Connell, B.; Healy, M.G.; O'Connor, I.; Officer, R.; Nash, R.; Morrison, L. Microplastics in Sewage Sludge: Effects of Treatment. Environ. Sci. Technol. 2017, 51, 810-818. [CrossRef] [PubMed]

87. ECHA. Zinc Chloride; Technical Report 231-592-0; European Chemicals Agency: Helsinki, Finnland, 2020.

88. ECHA. Sodium Iodide; Technical Report 231-679-3; European Chemicals Agency: Helsinki, Finnland, 2020.

89. Zobkov, M.B.; Esiukova, E.E. Evaluation of the Munich Plastic Sediment Separator efficiency in extraction of microplastics from natural marine bottom sediments. Limnol. Oceanogr. Methods 2017, 15, 967-978. [CrossRef]

90. Prendergast-Miller, M.T.; Katsiamides, A.; Abbass, M.; Sturzenbaum, S.R.; Thorpe, K.L.; Hodson, M.E. Polyester-derived microfibre impacts on the soil-dwelling earthworm Lumbricus terrestris. Environ. Pollut. 2019, 251, 453-459. [CrossRef]

91. Ballent, A.; Corcoran, P.L.; Madden, O.; Helm, P.A.; Longstaffe, F.J. Sources and sinks of microplastics in Canadian Lake Ontario nearshore tributary and beach sediments. Mar. Pollut. Bull. 2016, 110, 383-395. [CrossRef] [PubMed] 
92. Enders, K.; Käppler, A.; Biniasch, O.; Feldens, P.; Stollberg, N.; Lange, X.; Fischer, D.; Eichhorn, K.J.; Pollehne, F.; Oberbeckmann, S.; et al. Tracing microplastics in aquatic environments based on sediment analogies. Sci. Rep. 2019, 9. [CrossRef]

93. Corcoran, P.L.; Biesinger, M.C.; Grifi, M. Plastics and beaches: A degrading relationship. Mar. Pollut. Bull. 2009, 58, 80-84. [CrossRef]

94. Hurley, R.R.; Lusher, A.L.; Olsen, M.; Nizzetto, L. Validation of a Method for Extracting Microplastics from Complex, Organic-Rich, Environmental Matrices. Environ. Sci. Technol. 2018, 52, 7409-7417. [CrossRef]

95. Dekiff, J.H.; Remy, D.; Klasmeier, J.; Fries, E. Occurrence and spatial distribution of microplastics in sediments from Norderney. Environ. Pollut. 2014, 186, 248-256. [CrossRef]

96. Zhou, Q.; Zhang, H.; Fu, C.; Zhou, Y.; Dai, Z.; Li, Y.; Tu, C.; Luo, Y. The distribution and morphology of microplastics in coastal soils adjacent to the Bohai Sea and the Yellow Sea. Geoderma 2018, 322, 201-208. [CrossRef]

97. Anastas, P.; Eghbali, N. Green Chemistry: Principles and Practice. Chem. Soc. Rev. 2010, 39, 301-312. [CrossRef] [PubMed]

98. Kedzierski, M.; Le Tilly, V.; César, G.; Sire, O.; Bruzaud, S. Efficient microplastics extraction from sand. A cost effective methodology based on sodium iodide recycling. Mar. Pollut. Bull. 2017, 115, 120-129. [CrossRef] [PubMed]

99. Rodrigues, M.; Gonçalves, A.; Gonçalves, F.; Abrantes, N. Improving cost-efficiency for MPs density separation by zinc chloride reuse. MethodsX 2020, 7, 100785. [CrossRef]

100. Imhof, H.K.; Schmid, J.; Niessner, R.; Ivleva, N.P.; Laforsch, C. A novel, highly efficient method for the separation and quantification of plastic particles in sediments of aquatic environments. Limnol. Oceanogr. Methods 2012, 10, 524-537. [CrossRef]

101. Klein, S.; Worch, E.; Knepper, T.P. Occurrence and Spatial Distribution of Microplastics in River Shore Sediments of the Rhine-Main Area in Germany. Environ. Sci. Technol. 2015, 49, 6070-6076. [CrossRef]

102. Mahat, S. Separation and Quantification of Microplastics from Beach and Sediment Samples Using the Bauta Microplastic-Sediment Separator. Master's Thesis, Norwegian University of Life Sciences, As, Norway, 2017.

103. Han, X.; Lu, X.; Vogt, R.D. An optimized density-based approach for extracting microplastics from soil and sediment samples. Environ. Pollut. 2019, 254, 113009. [CrossRef]

104. Besley, A.; Vijver, M.G.; Behrens, P.; Bosker, T. A standardized method for sampling and extraction methods for quantifying microplastics in beach sand. Mar. Pollut. Bull. 2017, 114, 77-83. [CrossRef]

105. Nakajima, R.; Lindsay, D.J.; Tsuchiya, M.; Matsui, R.; Kitahashi, T.; Fujikura, K.; Fukushima, T. A small, stainless-steel sieve optimized for laboratory beaker-based extraction of microplastics from environmental samples. MethodsX 2019, 6, 1677-1682. [CrossRef] [PubMed]

106. Vermeiren, P.; Muñoz, C.; Ikejima, K. Microplastic identification and quantification from organic rich sediments: A validated laboratory protocol. Environ. Pollut. 2020, 262, 114298. [CrossRef] [PubMed]

107. Coppock, R.L.; Cole, M.; Lindeque, P.K.; Queirós, A.M.; Galloway, T.S. A small-scale, portable method for extracting microplastics from marine sediments. Environ. Pollut. 2017, 230, 829-837. [CrossRef] [PubMed]

108. Mintenig, S.M.; Int-Veen, I.; Löder, M.; Primpke, S.; Gerdts, G. Identification of microplastic in effluents of waste water treatment plants using focal plane array-based micro-Fourier-transform infrared imaging. Water Res. 2017, 108, 365-372. [CrossRef]

109. Löder, M.G.J.; Kuczera, M.; Mintenig, S.; Lorenz, C.; Gerdts, G. Focal plane array detector-based micro-Fourier-transform infrared imaging for the analysis of microplastics in environmental samples. Environ. Chem. 2015, 12, 563. [CrossRef]

110. Dehaut, A.; Cassone, A.L.; Frère, L.; Hermabessiere, L.; Himber, C.; Rinnert, E.; Rivière, G.; Lambert, C.; Soudant, P.; Huvet, A.; et al. Microplastics in seafood: Benchmark protocol for their extraction and characterization. Environ. Pollut. 2016, 215, 223-233. [CrossRef]

111. Kühn, S.; van Werven, B.; van Oyen, A.; Meijboom, A.; Bravo Rebolledo, E.L.; van Franeker, J.A. The use of potassium hydroxide $(\mathrm{KOH})$ solution as a suitable approach to isolate plastics ingested by marine organisms. Mar. Pollut. Bull. 2017, 115, 86-90. [CrossRef]

112. Duan, J.; Han, J.; Zhou, H.; Lau, Y.L.; An, W.; Wei, P.; Cheung, S.G.; Yang, Y.; Tam, N.F.Y. Development of a digestion method for determining microplastic pollution in vegetal-rich clayey mangrove sediments. Sci. Total Environ. 2020, 707, 136030. [CrossRef] 
113. Petigara, B.R.; Blough, N.V.; Mignerey, A.C. Mechanisms of Hydrogen Peroxide Decomposition in Soils. Environ. Sci. Technol. 2002, 36, 639-645. [CrossRef]

114. Mikutta, R.; Kleber, M.; Kaiser, K.; Jahn, R. Organic matter removal from soils using hydrogen peroxide, sodium hypochlorite, and disodium peroxodisulfate. Soil Sci. Soc. Am. J. 2005, 69, 120. [CrossRef]

115. Cole, M.; Webb, H.; Lindeque, P.K.; Fileman, E.S.; Halsband, C.; Galloway, T.S. Isolation of microplastics in biota-rich seawater samples and marine organisms. Sci. Rep. 2014, 4, 4528. [CrossRef]

116. Courtene-Jones, W.; Quinn, B.; Murphy, F.; Gary, S.F.; Narayanaswamy, B.E. Optimisation of enzymatic digestion and validation of specimen preservation methods for the analysis of ingested microplastics. Anal. Methods 2017, 9, 1437-1445. [CrossRef]

117. Railo, S.; Talvitie, J.; Setälä, O.; Koistinen, A.; Lehtiniemi, M. Application of an enzyme digestion method reveals microlitter in Mytilus trossulus at a wastewater discharge area. Mar. Pollut. Bull. 2018, 130, 206-214. [CrossRef]

118. Lavers, J.L.; Stivaktakis, G.; Hutton, I.; Bond, A.L. Detection of ultrafine plastics ingested by seabirds using tissue digestion. Mar. Pollut. Bull. 2019, 142, 470-474. [CrossRef]

119. Ljung, E.; Olesen, K.B.; Andersson, P.G.; Fältström, E.; Vollertsen, J.; Wittgren, H.B.; Hagman, M. Microplastics in the Water and Nutrient-Cycle; Technical Report 2018-13; Sweden Water Research: Bromma, Sweden, 2018.

120. Fabbri, D.; Tartari, D.; Trombini, C. Analysis of poly(vinyl chloride) and other polymers in sediments and suspended matter of a coastal lagoon by pyrolysis-gas chromatography-mass spectrometry. Anal. Chim. Acta 2000, 413, 3-11. [CrossRef]

121. Peez, N.; Becker, J.; Ehlers, S.M.; Fritz, M.; Fischer, C.B.; Koop, J.H.E.; Winkelmann, C.; Imhof, W. Quantitative analysis of PET microplastics in environmental model samples using quantitative 1H-NMR spectroscopy: Validation of an optimized and consistent sample clean-up method. Anal. Bioanal. Chem. 2019, 411, 7409-7418. [CrossRef]

122. Dierkes, G.; Lauschke, T.; Becher, S.; Schumacher, H.; Földi, C.; Ternes, T. Quantification of microplastics in environmental samples via pressurized liquid extraction and pyrolysis-gas chromatography. Anal. Bioanal. Chem. 2019, 411, 6959-6968. [CrossRef]

123. Fuller, S.; Gautam, A. A Procedure for Measuring Microplastics using Pressurized Fluid Extraction. Environ. Sci. Technol. 2016, 50, 5774-5780. [CrossRef]

124. Okoffo, E.D.; Ribeiro, F.; O’Brien, J.W.; O’Brien, S.; Tscharke, B.J.; Gallen, M.; Samanipour, S.; Mueller, J.F.; Thomas, K.V. Identification and quantification of selected plastics in biosolids by pressurized liquid extraction combined with double-shot pyrolysis gas chromatography-mass spectrometry. Sci. Total Environ. 2020, 715, 136924. [CrossRef]

125. Siotto, M.; Zoia, L.; Tosin, M.; Innocenti, F.D.; Orlandi, M.; Mezzanotte, V. Monitoring biodegradation of poly(butylene sebacate) by Gel Permeation Chromatography 1H-NMR and 31P-NMR techniques. J. Environ. Manag. 2013, 116, 27-35. [CrossRef] [PubMed]

126. Nelson, T.F.; Remke, S.C.; Kohler, H.P.E.; McNeill, K.; Sander, M. Quantification of Synthetic Polyesters from Biodegradable Mulch Films in Soils. Environ. Sci. Technol. 2019. [CrossRef] [PubMed]

127. Elert, A.M.; Becker, R.; Duemichen, E.; Eisentraut, P.; Falkenhagen, J.; Sturm, H.; Braun, U. Comparison of different methods for MP detection: What can we learn from them and why asking the right question before measurements matters? Environ. Pollut. 2017, 231, 1256-1264. [CrossRef] [PubMed]

128. La Nasa, J.; Biale, G.; Mattonai, M.; Modugno, F. Microwave-assisted solvent extraction and double-shot analytical pyrolysis for the quali-quantitation of plasticizers and microplastics in beach sand samples. J. Hazard. Mater. 2020, 401, 123287. [CrossRef]

129. Ceccarini, A.; Corti, A.; Erba, F.; Modugno, F.; Nasa, J.L.; Bianchi, S.; Castelvetro, V. The Hidden Microplastics: New Insights and Figures from the Thorough Separation and Characterization of Microplastics and of Their Degradation Byproducts in Coastal Sediments. Environ. Sci. Technol. 2018, 52, 5634-5643. [CrossRef] [PubMed]

130. Felsing, S.; Kochleus, C.; Buchinger, S.; Brennholt, N.; Stock, F.; Reifferscheid, G. A new approach in separating microplastics from environmental samples based on their electrostatic behavior. Environ. Pollut. 2018, 234, 20-28. [CrossRef]

131. Grbic, J.; Nguyen, B.; Guo, E.; You, J.B.; Sinton, D.; Rochman, C.M. Magnetic Extraction of Microplastics from Environmental Samples. Environ. Sci. Technol. Lett. 2019, 6, 68-72. [CrossRef] 
132. Crichton, E.M.; Noël, M.; Gies, E.A.; Ross, P.S. A novel density-independent and FTIR-compatible approach for the rapid extraction of microplastics from aquatic sediments. Anal. Methods 2017, 9, 1419-1428. [CrossRef]

133. Mani, T.; Frehland, S.; Kalberer, A.; Burkhardt-Holm, P. Using castor oil to separate microplastics from four different environmental matrices. Anal. Methods 2019, 11, 1788-1794. [CrossRef]

134. Scopetani, C.; Chelazzi, D.; Mikola, J.; Leiniö, V.; Heikkinen, R.; Cincinelli, A.; Pellinen, J. Olive oil-based method for the extraction quantification and identification of microplastics in soil and compost samples. Sci. Total Environ. 2020, 733, 139338. [CrossRef]

135. Lusher, A.L.; Bråte, I.L.N.; Munno, K.; Hurley, R.R.; Welden, N.A. Is It or Isn't It: The Importance of Visual Classification in Microplastic Characterization. Appl. Spectrosc. 2020. [CrossRef]

136. Filella, M. Questions of size and numbers in environmental research on microplastics: Methodological and conceptual aspects. Environ. Chem. 2015, 12, 527. [CrossRef]

137. Zhang, S.; Liu, X.; Hao, X.; Wang, J.; Zhang, Y. Distribution of low-density microplastics in the mollisol farmlands of northeast China. Sci. Total Environ. 2020, 708, 135091. [CrossRef]

138. Corradini, F.; Bartholomeus, H.; Huerta Lwanga, E.; Gertsen, H.; Geissen, V. Predicting soil microplastic concentration using vis-NIR spectroscopy. Sci. Total Environ. 2019, 650, 922-932. [CrossRef] [PubMed]

139. Helmberger, M.S.; Frame, M.K.; Grieshop, M. Counterstaining to Separate Nile Red-Stained Microplastic Particles from Terrestrial Invertebrate Biomass. Environ. Sci. Technol. 2020, 54, 5580-5588. [CrossRef]

140. Nel, H.A.; Chetwynd, A.J.; Kelleher, L.; Lynch, I.; Mansfield, I.; Margenat, H.; Onoja, S.; Goldberg Oppenheimer, P.; Sambrook Smith, G.H. Detection Limits Are Central to Improve Reporting Standards When Using Nile Red for Microplastic Quantification. Chemosphere 2021, 263, 127953. [CrossRef]

141. Anger, P.M.; von der Esch, E.; Baumann, T.; Elsner, M.; Niessner, R.; Ivleva, N.P. Raman microspectroscopy as a tool for microplastic particle analysis. TrAC Trends Anal. Chem. 2018, 109, 214-226. [CrossRef]

142. Xu, J.L.; Thomas, K.V.; Luo, Z.; Gowen, A.A. FTIR and Raman imaging for microplastics analysis: State of the art challenges and prospects. TrAC Trends Anal. Chem. 2019, 119, 115629. [CrossRef]

143. Lares, M.; Ncibi, M.C.; Sillanpää, M.; Sillanpää, M. Intercomparison study on commonly used methods to determine microplastics in wastewater and sludge samples. Environ. Sci. Pollut. Res. 2019, 26, 12109-12122. [CrossRef]

144. Simon, M.; van Alst, N.; Vollertsen, J. Quantification of microplastic mass and removal rates at wastewater treatment plants applying Focal Plane Array (FPA)-based Fourier Transform Infrared (FT-IR) imaging. Water Res. 2018, 142, 1-9. [CrossRef]

145. David, J.; Steinmetz, Z.; Kučerík, J.; Schaumann, G.E. Quantitative Analysis of Poly(ethylene terephthalate) Microplastics in Soil via Thermogravimetry-Mass Spectrometry. Anal. Chem. 2018, 90, 8793-8799. [CrossRef]

146. Boyron, O.; Marre, T.; Delauzun, A.; Cozic, R.; Boisson, C. An Advanced Technique for Linear Low-Density Polyethylene Composition Determination: TGA-IST16-GC-MS Coupling. Macromol. Chem. Phys. 2019, 220, 1900162. [CrossRef]

147. Dümichen, E.; Eisentraut, P.; Bannick, C.G.; Barthel, A.K.; Senz, R.; Braun, U. Fast identification of microplastics in complex environmental samples by a thermal degradation method. Chemosphere 2017, 174, 572-584. [CrossRef] [PubMed]

148. Fischer, M.; Scholz-Böttcher, B.M. Microplastics analysis in environmental samples-Recent pyrolysis-gas chromatography-mass spectrometry method improvements to increase the reliability of mass-related data. Anal. Methods 2019, 11, 2489-2497. [CrossRef]

149. La Nasa, J.; Biale, G.; Fabbri, D.; Modugno, F. A review on challenges and developments of analytical pyrolysis and other thermoanalytical techniques for the quali-quantitative determination of microplastics. J. Anal. Appl. Pyrolysis 2020, 149, 104841. [CrossRef]

150. Nguyen, B.; Claveau-Mallet, D.; Hernandez, L.M.; Xu, E.G.; Farner, J.M.; Tufenkji, N. Separation and Analysis of Microplastics and Nanoplastics in Complex Environmental Samples. Accounts Chem. Res. 2019, 52, 858-866. [CrossRef] [PubMed]

151. Sullivan, G.; Gallardo, J.D.; Jones, E.; Hollliman, P.; Watson, T.; Sarp, S. Detection of trace sub-micron (nano) plastics in water samples using pyrolysis-gas chromatography time of flight mass spectrometry (PY-GCToF). Chemosphere 2020, 249, 126179. [CrossRef] [PubMed]

152. Becker, R.; Altmann, K.; Sommerfeld, T.; Braun, U. Quantification of microplastics in a freshwater suspended organic matter using different thermoanalytical methods-Outcome of an interlaboratory comparison. J. Anal. Appl. Pyrolysis 2020, 148, 104829. [CrossRef] 
153. Schirinzi, G.F.; Llorca, M.; Seró, R.; Moyano, E.; Barceló, D.; Abad, E.; Farré, M. Trace analysis of polystyrene microplastics in natural waters. Chemosphere 2019, 236, 124321. [CrossRef]

154. Drzeżdżon, J.; Jacewicz, D.; Sielicka, A.; Chmurzyński, L. A review of new approaches to analytical methods to determine the structure and morphology of polymers. TrAC Trends Anal. Chem. 2019, 118, 470-476. [CrossRef]

155. Peez, N.; Janiska, M.C.; Imhof, W. The first application of quantitative 1 H NMR spectroscopy as a simple and fast method of identification and quantification of microplastic particles (PE PET and PS). Anal. Bioanal. Chem. 2018, 411, 823-833. [CrossRef]

156. Peez, N.; Imhof, W. Quantitative 1 H-NMR spectroscopy as an efficient method for identification and quantification of PVC ABS and PA microparticles. Analyst 2020, 145, 5363-5371. [CrossRef] [PubMed]

157. Watteau, F.; Dignac, M.F.; Bouchard, A.; Revallier, A.; Houot, S. Microplastic Detection in Soil Amended With Municipal Solid Waste Composts as Revealed by Transmission Electronic Microscopy and Pyrolysis/GC/MS. Front. Sustain. Food Syst. 2018, 2. [CrossRef]

158. Du, C.; Wu, J.; Gong, J.; Liang, H.; Li, Z. ToF-SIMS characterization of microplastics in soils. Surf. Interface Anal. 2020, 52, 293-300. [CrossRef]

159. Paul, A.; Wander, L.; Becker, R.; Goedecke, C.; Braun, U. High-throughput NIR spectroscopic (NIRS) detection of microplastics in soil. Environ. Sci. Pollut. Res. 2019, 26, 7364-7374. [CrossRef]

Publisher's Note: MDPI stays neutral with regard to jurisdictional claims in published maps and institutional affiliations.

(C) 2020 by the authors. Licensee MDPI, Basel, Switzerland. This article is an open access article distributed under the terms and conditions of the Creative Commons Attribution (CC BY) license (http://creativecommons.org/licenses/by/4.0/). 